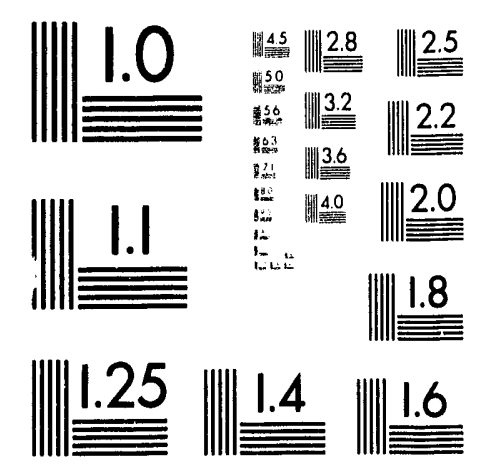



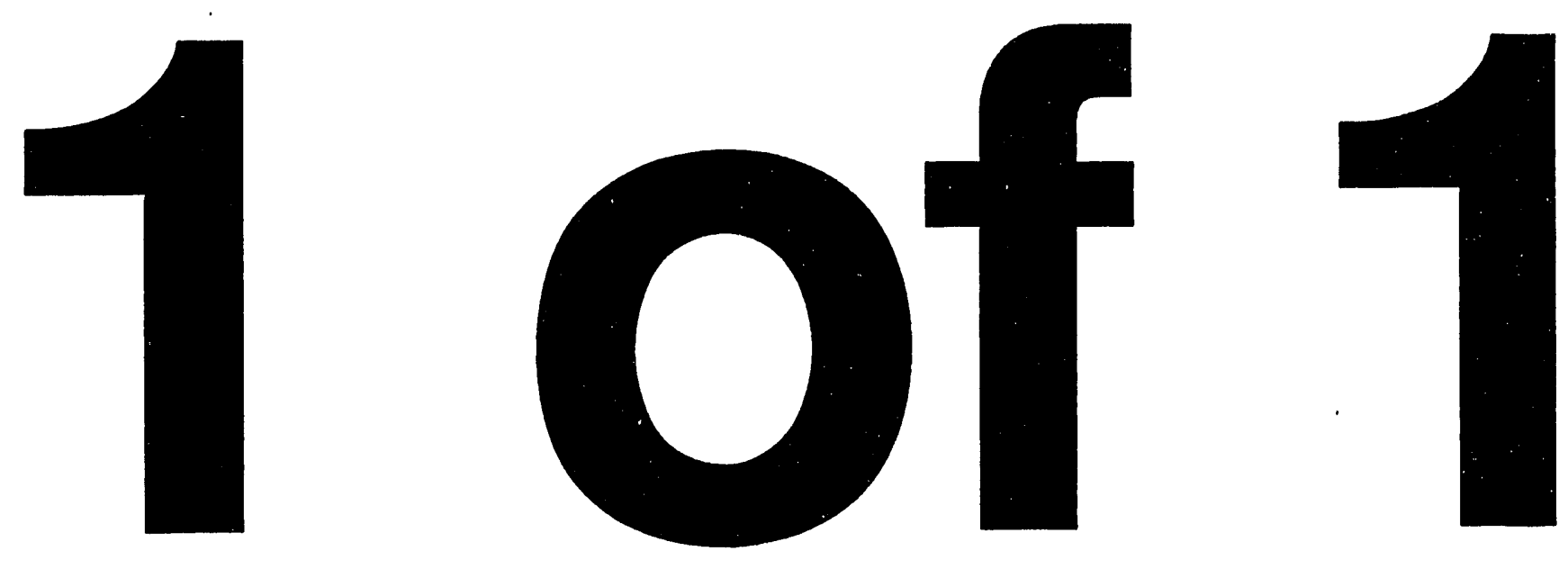


\title{
U.S. Production of Natural Gas from Tight Reservoirs
}

\section{October 1993}

\author{
Energy Information Administration \\ Office of Oil and Gas \\ U.S. Department of Energy \\ Washington, DC 20585
}

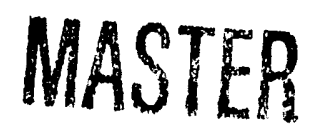

This report was prepared by the Energy Information Administration, the independent statistical and analytical agency within the Department of Energy. The information contained herein should not be construed as advocating or reflecting any policy position of the Department of Energy or any other organization. 


\section{Contacts}

This report was prepared by the Energy Information Administration's Office of Oil and Gas, under the general direction of Diane W. Lique, Director of the Reserves and Natural Gas Division; Craig H. Cranston, Chief of the Reserves and Production Branch; and David F. Morehouse, Supervisory Geologist. Information regarding the report's content may be obtained from the author, Herbert T. Black (202) 586-4055, or from David Morehouse (202) $586-4853$. 


\section{Preface}

This report by the Energy Information Administration's (EIA) Office of Oil and Gas is the fifth in a series of reports focused on domestic gas production from unconventional types of reservoirs. It is the third to address tight gas production levels. Two prior reports have dealt with the full range of unconventional gas production, Drilling and Production Under Title I of the Natural Gas Policy Act, 1978-1986 (1989) and Natural Gas Production Responses to a Changing Market Environment, 1978-1988 (1990). Two additional reports have dealt with coalbed methane production, Status of Coalhed Methane Recovery in the United States (1988) and Update on U.S. Coalbed Methane Production (1990).

The author acknowledges the assistance provided by Philip Shambaugh and Robert King in relation to the preparation of the production data reported here. 


\section{Contents}

Page

1. Introduction $\ldots \ldots \ldots \ldots \ldots \ldots \ldots \ldots \ldots \ldots \ldots \ldots \ldots \ldots \ldots \ldots \ldots$

2. Past Studies $\ldots \ldots \ldots \ldots \ldots \ldots \ldots \ldots \ldots \ldots \ldots \ldots \ldots \ldots \ldots \ldots \ldots$

3. Factors Unique to Tight Gas Resources Development $\ldots \ldots \ldots \ldots \ldots \ldots \ldots$

The Natural Gas Policy Act and FERC Section 107 Tight Gas Designation . . . . . . . . 5

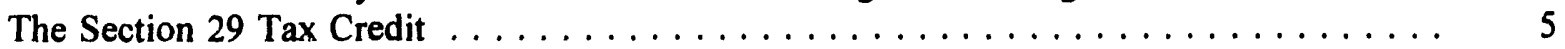

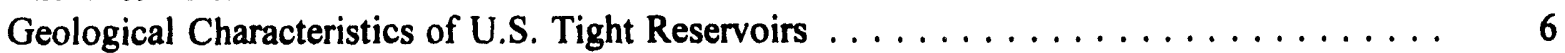

Tight Gas Production Technology $\ldots \ldots \ldots \ldots \ldots \ldots \ldots \ldots \ldots \ldots \ldots \ldots \ldots$

4. The EIA's Calculation of Production from Tight Reservoirs $\ldots \ldots \ldots \ldots \ldots \ldots$

5. U.S. Basins with Tight Gas Production $\ldots \ldots \ldots \ldots \ldots \ldots \ldots \ldots \ldots$

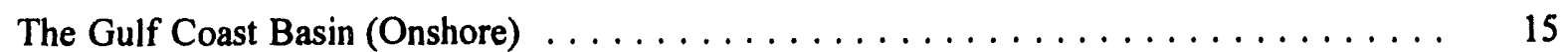

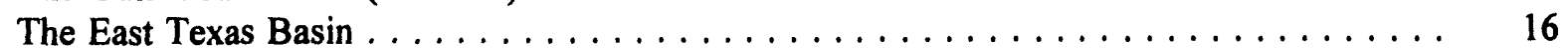

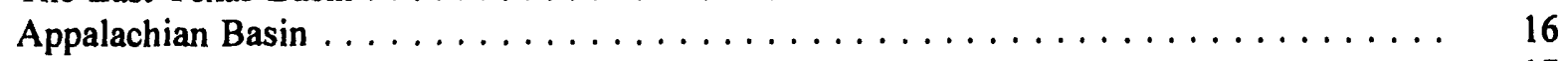

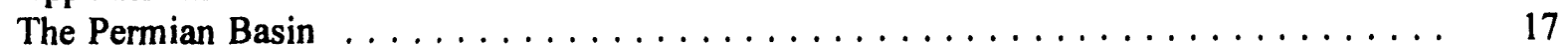

The Denver Basin . . . . . . . . . . . . . . . . . . . . . . . . . . . . . 17

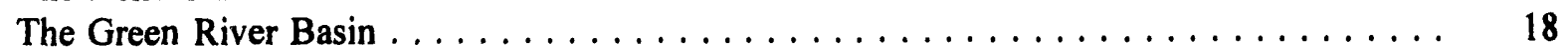

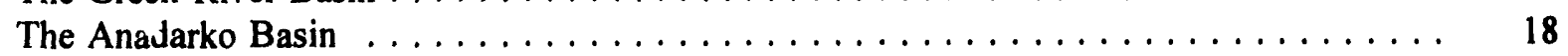

The Central Western Overthrust $\ldots \ldots \ldots \ldots \ldots \ldots \ldots \ldots \ldots \ldots \ldots \ldots \ldots \ldots \ldots$

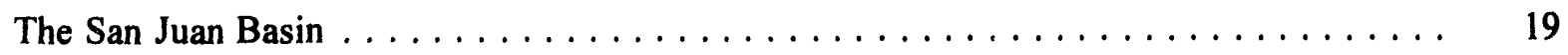

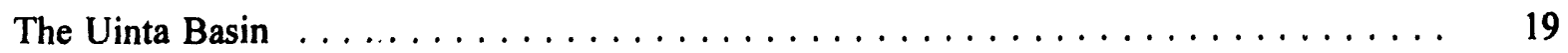

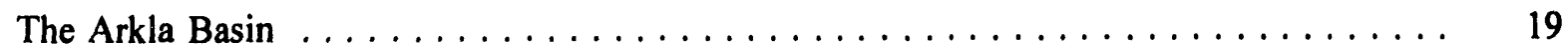

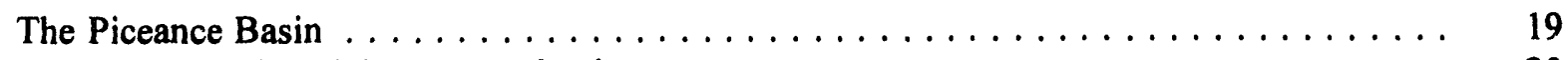

Other Basins with Tight Gas Production $\ldots \ldots \ldots \ldots \ldots \ldots \ldots \ldots \ldots \ldots \ldots \ldots \ldots$

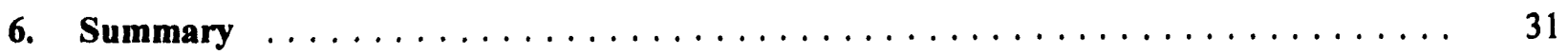

\section{Tables}

1. Tight Gas Production from Wells Eligible for the Section 29 Tax Credit by

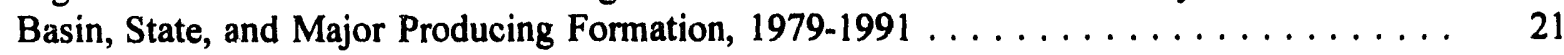

2. Production of Tight Gas from Wells Eligible for the Section 29 Tax Credit

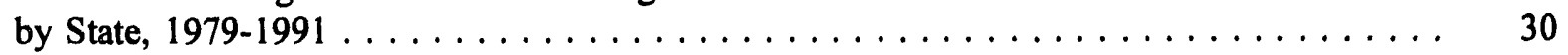

\section{Figure}

1. Principal Basins Producing Tight Gas, $1991 \ldots \ldots \ldots \ldots \ldots \ldots \ldots$ 


\section{Introduction}

About 90 percent of United States natural gas production comes from conventional gas reservoirs. The remainder comes from a variety of nonconventional sources, the most volumetrically important of which consists of so-called tight gas reservoirs. The principal distinction between conventional and tight gas reservoirs lies in their marked differences of production rate capability. The initial production rates of tight reservoirs, as compared to those of conventional reservoirs, are very low. This often renders them economically marginal. Consequently, some kind of economic incentive must often be present to induce operators to explore for and develop their gas resources.

Since 1980 the Federal Government has allowed operators of new domestic wells drilled into tight gas reservoirs to take either a tax credit on the resulting production or to charge an incentive price that is prescribed relative to the price of oil. The unitary purpose of the Crude Oil Wiridfall Profits Tax Act's Section 29 tax credit, and the incentive pricing provided under Section 107 of the Natural Gas Policy Act of 1978, was to stimulate exploration for, and development of, these technically difficult and economically marginal nonconventional gas reservoirs, especially during times of low oil prices.

For the purposes of this report, tight gas reservoirs are defined as those that meet the Federal Energy Regulatory Commission's (FERC) definition of right. They are generally characterized by an average reservoir rock permeability' to gas of 0.1 millidarcy or less and, absent artificial stimulation of production, by production rates that do not exceed 5 barrels of oil per day and certain specified daily volumes of gas which increase with the depth of the reservoir. ${ }^{2}$ All of the statistics presented in this report pertain to wells that have been classified, from 1978 through 1991, as tight according to the FERC; i.e., they are "legally tight" reservoirs. Additional production from "geologically tight" reservoirs that have not been classified tight according to the FERC rules has been excluded. This category includes all producing wells drilled into legally designated tight gas reservoirs prior to 1978 and all producing wells drilled into physically tight gas reservoirs that have not been designated legally tight. Therefore, all gas production referenced herein is eligible for the Section 29 tax credit. Although the qualification period for the credit expired at the end of 1992, wells that were spudded (began to be drilled) between 1978 and May 1988, and from Novenber 5, 1990, through year end 1992, are eligible for the tax credit for a subsequent period of 10 years.

Based on the above definition of tight gas, United States tight gas production increased from the 69 billion cubic feet obtained from 3,052 wells in 1979, to the 1,264 billion cubic feet obtained from 55,645 wells in 1991. Tight gas production accounted for almost 7 percent of total United States natural gas production in 1991. This report updates the EIA's tight gas production information through 1991 and considers further the history and effect on tight gas production of the Federal Government's regulatory and tax policy actions. It also provides some high points of the geologic background needed to understand the nature and location of low-permeability reservoirs.

\footnotetext{
' The permeability of a rock is a measure of its ability to conduct fluid flow through interconnections of the pores that exist between the mineral grains that make up the solid portion of the rock.

${ }^{2}$ 18CFR, Chapter 1, Subchapter H - First Sale Regulation Under the Natural Gas Policy Act of 1978, Subpart G - High Cost Natural Gas, Section 271.703 Tight Formations, Federal Energy Regulatory Commission, April 1, 1991.
} 


\section{Past Studies}

The EIA previously published two studies about United States gas production that included production data for nonconventional gas resources. The most recent one covered data through 1988 for tight gas, Devonian shales, and deep gas. ${ }^{34}$ The EIA has published two related studies of United States coalbed methane production which document results of the drilling boom for that resource stimulated by availability of the Section 29 tax $^{\text {credit. }^{56}}$

Also, a report written for the Gas Research Institute (GRI) by Energy and Environmental Analysis, Inc. (EEA) provided tight gas production estimates for the United States, excluding the Appalachian region, through $1988 .{ }^{7}$ EEA's methodology caused the GRI production estimates to be higher than the EIA's due to the fact that EEA included some production from geologically tight formation areas that were not legally designated as tight by the FERC.

As noted above, the EIA decided to strictly limit its tight gas production estimates to tight gas production obtained from FERC-designated wells, and to only that time period after they were legally designated tight (i.e., production was not extrapolated backward in time even though it might have been known that a particular reservoir was producing before its FERC approval date). The EIA's tight gas production volumes are therefore minimums that can be reliably used to show how much tight gas has become eligible for the Section 29 tax credit.

\footnotetext{
${ }^{3}$ Energy Information Administration, Drilling and Production Under Title I of the Natural Gas Policy Act, 1978-1986, DOE/EIA0448(86) (Washington, DC, January 1989).

${ }^{4}$ Energy Information Administration, Natural Gas Production Responses to a Changing Market Environment, 1978-1988, DOE/EIA0532 (Washington, DC, May 1990).

${ }^{5}$ David Murchison, "Status of Coalbed Methane Recovery in the United States," Natural Gas Monthly, September 1988, DOE/EIA0130(88/09) (Washington, DC, December 1988).

${ }^{6}$ Herbert T. Black, "Update on U.S. Coalbed Methane Production," Natural Gas Monthly, October 1990, DOE/LIA-0130(90/10) (Washington, DC, December 1990).

${ }^{7}$ R.H. Hugman, P.S. Springer, and E.H. Vidas, Tight Gas Field, Reservoir, and Completion Analysis of the United States, Volume I, Project Summary (Arlington, VA: Energy and Environmental Analysis, Inc., April 1992).
} 


\section{Factors Unique to Tight Gas Resources Development}

\section{The Natural Gas Policy Act and FERC Section 107 Tight Gas Designation}

The Natural Gas Policy Act (NGPA, Public Law 95-621), signed into law on November 9, 1978, represented a compromise that followed some 18 months of congressional debate. The House of Representatives had initially passed a bill deregulating interstate natural gas prices (intrastate sales of natural gas had never been federally regulated), while the Senate had initially passed a bill extending Federal price regulation to intrastate gas sales. Prior to this, interstate natural gas sales prices had been federally controlled at below-market clearing levels, and an imbalance had therefore developed between interstate and intrastate gas prices, causing loss of supply to interstate commerce. Indeed, at the time the Congress was considering the NGPA, increasing oil prices and demand and declining supplies of natural gas had resulted in severe gas shortages, resulting in curtailments of contracted delivery in many parts of the United States.

The NGPA was designed primarily to facilitate a transition to decontrolled natural gas prices by 1985 . However, another purpose was to encourage exploration for, and development of, nonconventional and typically high-cost gas resources. Section 107 of the NGPA defined high-cost natural gas as gas produced from (1) a well spudded after February 19, 1977, and completed deeper than 15,000 feet, (2) geopressured brine, (3) coal seams, and (4) Devonian shale. All four of these categories of high-cost gas were deregulated on November 1, 1979, via a FERC ruling. ${ }^{8}$

The NGPA also permitted the FERC to identify gas that was produced under conditions of extraordinary risk or cost and to thereafter establish a maximum lawful price "... necessary to provide reasonable incentives for the production of such gas." Tight formation gas was thus identified and defined by a FERC ruling effective March 21, 1980, and thereby became eligible for incentive pricing, ultimately until January 1, 1985. Tight gas was given the highest ceiling price of any NGPA regulated category. A tax credit, described in the next section, was also available, but producers had to elect either the credit or the incentive price. To receive either benefit, producers were required to prove that the reservoir was eligible to be designated tight according to the FERC's criteria. The State regulatory body that had jurisdiction over the geographic area of the reservoir served as the approving body.

\section{The Section 29 Tax Credit}

From December 31, 1979, until May 1988, and from November 5, 1990, until December 31, 1992, tax credits were made available for the production of tight gas under Section 29 of the Crude Oil Windfall Profits Tax Act of 1980, which was twice amended to provide extensions of the end of the initial qualification period from December 31, 1989, to December 31, 1992. The amount of the tax credit for tight formation gas was set at 51.7 cents per million British thermal units (Btu). For comparison purposes, during the 1980 through 1992 period, the national annual average wellhead price of natural gas ranged between $\$ 1.54$ and $\$ 2.58$ per million Btu.

\footnotetext{
${ }^{8}$ Energy Information Administration, Drilling and Production Under Title I of the Natural Gas Policy Act, 1978-1986, p. 36.
} 


\section{Geological Characteristics of U.S. Tight Reservoirs}

The original porosities and permeabilities of gas-bearing sedimentary reservoir rocks are initially determined by their environments of deposition. However, post-depositional physical and chemical changes that occur at depth during a process called diagenesis often significantly alter a rock's porosity and permeability, and hence its ability to produce gas. Most tight gas reservoir rocks originally had moderate to high porosity and permeability when deposited, but compaction due to deep burial of the rock and the precipitation of cements into the spaces between the mineral grains that form the solid portion of the rock have reduced these properties.

Older and deeper sandstones generally are tighter than younger or shallower rocks because they have been buried more deeply, which allows more cementation and compaction to occur. Most United States tight gas reservoirs are of the Paleozoic (570-245 million years old) or Mesozoic (245-66 million years old) Eras. The only younger FERC-designated tight gas sandstones are the Wilcox and Vicksburg of the Texas Gulf Coast, both of which date to the Tertiary Era (66-1.6 million years old) and are deeply buried," and the Wasatch of the Uinta Basin, which is also Tertiary.

For fluids such as natural gas to flow easily through a rock, there must be good interconnection of the rock's pore spaces. Otherwise the rock simply stores the fluid. A tight reservoir rock may have much pore space but very low permeability because the pore spaces are not well interconnected. In such cases, it is often necessary to artificially fracture the rock to create connections to a well bore before economical production can be obtained. This is the objective of the expensive massive hydraulic fracturing completion techniques applied to many tight reservoirs.

According to work done by the U.S. Geological Survey, tight reservoir rocks are generally of two main types: high porosity (HP) and low porosity (LP). ${ }^{11}$ The HP type of tight reservoir rock has low permeability (less than one millidarcy) but can have good porosity, ranging from 10 to 30 percent in siltstones and very fine-grained sandstones and up to 40 percent in chalks. L.P reservoir rocks have less permeability on average than do HP rocks, and they also have low porosities, ranging from 3 to $1^{\prime}<$ percent. The porosity in LP, type rocks occurs in the form of small microvugs (isolated spaces). With such scattered porosity, these rocks neither hold as much gas as the HP type nor do they allow the gas to flow as well. Unfortunately, most United States tight gas is found in L.P type reservoir rocks."

A different classification of tight gas sandstones has been proposed based on pore geometry, which is an important factor relative to permeability. ${ }^{12}$ Type 1 sandstones have open pores, but the pore throats are largely blocked by authigenic clay minerals (clay minerals that formed during diagenesis after the deposition of the sediments). Type 2 sandstones have pores that are largely filled with authigenic cements (cements that precipitated during (liagenesis) such as quartz and calcite. The result is that the pores are very thin and typically connect larger secondary pores that were formed after deposition by the dissolution of adjacent mineral grains. Type 3 sandstones are "muddy sandstones," the intergranular pores of which are filled with original (detrital) clay minerals. Any porosity that remains in them is microporosity.

${ }^{4}$ S.P. Dutton and S.E. Laubach, "Comprehensive Geologic Basin Analysis: Application of a Generic Research Approach to Several Tight (ias Sandstone Formations," in In Focus-Tight Gas Sands (Washington, DC: Gas Research Institute, May 1993), pp. 5-6.

1" C.W. Spencer, "Geologic Aspects of Tight Gas Reservoirs in the Rocky Mountain Region," in.Journal of Petroleum Technology 37,8 (July 1985), pp. 1308-1314.

" C.W. Spencer, "Review of Characteristics of Low-Permeability Cias Reservoirs in the Western United States," in AmericanAssociation of Petroleum Geologists Bulletin 73,5 (May 1989), p. 614.

${ }^{12}$ D.J. Soeder and P. Chowdiah, "Pore Geometry in High- and Low-Permeability Sandstones, Travis Peak Formation, East Texas," in SPE Formation Evaluation 5, 4 (April 1990), pp. 421-430. 
Type 2 sandstones are the most common United States tight gas reservoir. Most Type 1 sandstones are co-existent with Type 2 reservoirs and are rare by themselves. Type 3 sandstones make the poorest reservoirs because they have had low porosity and permeability from the time of initial sediment deposition; therefore, not much gas could ever migrate into them. Further, because of their clay matrix, the compaction due to burial reduces their porosity and permeability even more.

To understand the nature of the most productive tight gas reservoirs covered in this report, it is necessary to understand a little about the "environment of deposition" of, post-depositional changes to, and natural fracture systems in, the reservoirs. "Environment of deposition" refers to where the rock-forming sediments were deposited, such as in a river (a fluvial environment), on a beach (a shoreface or marginal marine environment), or in the deep ocean (the marine environment). A depositional system (deposystem) is a group of rock layers that were deposited in similar environments of deposition, such as fluvial, fan delta, or subsea shelf environments. Tight gas reservoirs can be classified by their deposystem, which then allows similarly deposited reservoirs located in different places to be compared.

A report written by the University of rexas Bureau of Economic Geology for the Gas Research Institute has classified 24 major tight gas reservoirs by their deposystem. ${ }^{13}$ Significantly, eighteen of them are of the barrierstrandplain and deltaic types. These deposystems represent high-energy environments because of the wave action that occurs in them, which tends to make the sandstones "clean"; i.e., they do not contain much clay mineralization since the fine clay particles are washed out of them, while the coarser sand particles remain behind. 'This observation comports with the fact that most commercial tight gas reservoirs are Type 2, consisting of originally porous and permeable sandstones wherein the pores were occluded by authigenic cement after deposition. This diagenetic alteration of the originally clean sandstones is the major reason for the Type 2 reservoirs' low permeability. ${ }^{14}$ Secondarily, the original geometry of the sand bodies also has an effect on how natural and artificial fractures will be propagated in the reservoir rocks.

A fuither classification of tight reservoirs, useful at least for some located in the Western United States, is based on certain engineering and geologic characteristics. It divides them into either blanket or lenticular types. ${ }^{15}$ Blanket tight gas reservoirs tend to be more laterally continuous than lenticular ones and tend to respond to hydraulic fracturing in a predictable fashion. They may be either LP or HP type. The LP blanket reservoirs were originally conventionally porous and permeable formations that have since been altered through diagenesis to have a lower porosity and permeability. They can be either sandstones or carbonate rocks (such as limestones). The HP blanket reservoirs contain biogenic gas (gas that has been in the rock nearly from the time of its deposition, derived from the in-situ decomposition of organic material laid down contemporaneously and co-locationally with the reservoir sediment). These have never been conventional reservoirs, nor have their original porosity and permeability been reduced by subsequent events. It is thought that the presence of the biogenic gas prevented any post-burial geologic changes to these reservoirs' characteristics. They are mostly Upper Cretaceous, fine-grained clastic (sandstone and siltstone) rocks and chalks. It is estimated that there are large (on the order of 100 trillion cubic feet) recoverable resources of gas in these types of reservoirs in the Great Plains region. ${ }^{16}$

Lenticular reservoirs tend to be low porosity (LP) Cretaceous and Lower Tertiary fluvial (deposited in rivers) sandstones located in the deeper portions of the Rocky Mountain basins. These reservoir rocks have been altered,

${ }^{13}$ S.P. Dutton, et al., Atlas of Major Low-Permeability Sandstone Gas Reservoirs in the Continental United States, Topical Report No. GRI-93/0044 prepared for the Gas Research Institute (Austin, TX: The University of Texas Burcau of Economic Geology, 1992), pp. 12-14.

${ }^{14}$ S.P. Dutton, et al., Allas of Major Low-Permeability Sandstone Cias Reservoirs in the Continental United States, p. 10.

is C.W. Spencer, "Geologic Aspects of Tight Gas Reservoirs in the Rocky Mountain Region," pp. 1308-1314.

${ }^{16}$ D.D. Rice and G.W. Shurr, "Shallow Low-Permeability Reservoirs of the Northern Great Plains - An Assessment of their Natural Gas Resources," in American Association of Petroleum Geologists Bulletin 64, 7 (July 1980), pp. 969-987. 
and their pore spaces filled by cement, through the effects of deep burial and other processes. ${ }^{17}$ They are highly discontinuous, and it is difficult for the geologist to predict their location and extent. Their lateral discontinuity also causes fracturing techniques to be less predictable and effective, making their completion for production more difficult.

Tight reservoirs in general are difficult to work with for many reasons. The extra cost attached to artificial stimulation of the reservoir and the unpredictability of lenticular rocks have already been mentioned. Additionally, one of the main tools that geologists and engineers use to evaluate reservoirs, the geophysical well $\log$, is very difficult to interpret in tight reservoir rocks due to a variety of their geologic characteristics. ${ }^{18}$ This makes decisions about whether a porous reservoir is present--and if so, exactly where--much more problematical than in conventional reservoirs.

Once a discovery well has been drilled and tested, and a decision is made to produce the gas, it is very easy to damage a tight gas reservoil: As noted above, many tight reservoir rocks contain clay minerals, some of which swell when contacted by fresh water or can otherwise easily block the very small pore throats in the rock. The clay minerals also have a high surface-to-volume ratio, which increases the water saturation in the reservoir, lowering its reiative permeability to gas. ${ }^{19}$ However, careful planning during the drilling and completion phases can nevertheless often reduce these problems.

Yet another problem is that most tight gas reservoirs are either over- or underpressured. That is, the gas pressure in the reservoir is either substantially more or less than the normal hydrostatic pressure associated with the reservoir's depth. Most HP reservoirs are underpressured, while many LP reservoirs in the deep parts of the Rocky Mountain basins are overpressured. ${ }^{20}$ The abnormal reservoir pressures must be taken into account when a reservoir is drilled. For example, drilling unaware and unprepared into an overpressured gas reservoir can result in a well blowout. Underpressured reservoirs are more difficult to produce than conventional reservoirs because there is not as much pressure driving the gas to the surface. In some cases it may have to be compressed before it can be delivered into a pipeline.

Finally, some kind of artificial fracturing of tight gas reservoirs is usually necessary to sufficiently increase the near-wellbore permeability to gas of the reservoir rock to provide commercially viable production rates. These techniques must often be tailored for the specific area, and they are very expensive.

\section{Tight Gas Production Technology}

Because tight formations by definition have extremely low permeabilities to gas, natural flows (production rates) from wells conventionally completed in them are very low. Without some form of artificial stimulation of the reservoir or the implementation of some other kind of unusual production technique, typically more expensive than a conventional completion, the wells often are not economic. While a major purpose of the Section 29 tax credit was to encourage gas producers to explore for, and develop production from, unconventional gas resources, another important purpose was to induce and enable producers to develop and test new and more economical production enhancement techniques.

${ }^{17}$ C.W. Spencer, "Geologic Aspects of Tight Gas Reservoirs in the Rocky Mountain Region," p. 1308-1314.

${ }^{18}$ C.W. Spencer, "Review of Characteristics of Low-Permeability Gas Reservoirs in the Western United States," p. 621.

${ }^{19}$ S.P. Dutton and S.E. Laubach, "Comprehensive Geologic Basin Analysis: Application of a Generic Research Approach to Several Tight Gas Sandstone Formations," p. 6.

${ }^{20}$ C.W. Spencer, "Review of Characteristics of Low-Permeability Gas Reservoirs in the Western United States," p. 622. 
The combined 1979 through 1992 effect of the incentive pricing for Section 107 gas and the Section 29 tax credit was (as intended) stimulation of drilling for, and increased production of, unconventional gas. There are chree main types of technologies that are presently used to attempt to increase the production rates of low-permeability reservoirs. Their development for tight gas applications can largely be tied to the provided incentives. They are as follows:

1. Artificial fracturing, which creates fractures that intersect the reservoir's natural fracture system

2. Horizontal wells, which intersect the reservoir's natural fracture system at approximate right angles

3. Slim-hole wells that are drilled with closer than conventional spacings. ${ }^{21}$

In both artificial fracturing and horizontal drilling, natural fractures must already be present for the gas to be produced from tight gas reservoirs. Most rocks in the earth's shallow crust react to the application of stress in a brittle fashion, forming natural fractures. Because the earth's crust is made up of massive, constantly moving tectonic plates, compression of the ciustal rocks results from the collisions of the plates. The resulting compressive stress causes fractures to be created and propagated in the crustal rocks in directions that vary according to the directions of maximum and minimum stress. Fractures can also be formed by crustal extension, as in the Basin and Range Province of the Western United States where deep mantle material upwelling beneath the crust has caused the shallow crustal formations to be extended. Other mechanisms that can cause natural fractures to form in rocks include flexure, uplift, cooling, and fluid migration. ${ }^{22}$

Fractures can be classified according to their method of formation and by the relative movement of the fracture walls. Fractures that have walls which have moved perpendicularly to each other are called extension fractures. These tend to be open fractures unless they have been closed after their formation by subsequent compression or diagenesis. Fractures that have formed by lateral wall movements are called faults, which come in many different kinds, sizes, densities, and orientations. It is thought that natural fractures, of whatever type and origin, have increased the permeability to gas in virtually all productive tight reservoirs. ${ }^{23}$ These effects have been described in many tight reservoirs, such as the Cotton Valley of the East Texas Basin, the Mesaverde of the Piceance Basin, and the Frontier Formation of the Green River Basin.

In a hydraulic fracturing operation intended to stimulate tight gas production, knowledge of the orientation and nature of the natural fractures in the reservoir rock is the key to good results. Foreknowledge of the resident stress field is necessary, and there are indicators that reservoir engineers can use to ascertain the stress field in a given area. These are beyond the scope of this report. The interested reader may find more information on this topic in the Atlas of Major Low-Permeability Sandstone Reservoirs in the Continental United States.

\footnotetext{
${ }^{21}$ National Petroleum Council, The Potential for Natural Gas in the United States, Volume II - Source and Supply (Washington, DC, December 1992), pp. 93-94.

${ }^{22}$ P.L. Hancock, "Brittle Microtectonics: Principles and Practice," in Journal of Structural Geology 7, 3/4 (March 1985), pp. $437-458$.

${ }^{23}$ S.P. Dutton and S.E. Laubach, "Comprehensive Geologic Basin Analysis: Application of a Generic Research Approach to Several Tight Gas Sandstone Formations," p. 9.
} 


\section{The EIA's Calculation of Production from Tight Reservoirs}

The EIA's primary detailed data source on gas production is Dwight's Energydata, Inc. (Dwight's). Dwight's maintains production histories by well for all states located outside of the Northeast (the Appalachian area). Identification of the well includes its unique API (American Petroleum Institute) number, the field name, the reservoir name, and the lease name, in addition to information indicating when the well began production. The reservoir type is not provided.

To ascertain which wells were producing tight gas, a second data source was used. The FERC-121 form, "Application for Determination of NGPA Criteria," was instituted in 1978 pursuant to the Natural Gas Policy Act (NGPA). It is filed by producers to obtain FERC certification of the gas category under the NGPA. One of the categories is tight gas. The form asks for the unique API well number and the field and well names. The EIA accessed a cumulative file of the FERC-121 forms and extracted all FERC-certified tight gas wells. The extract file was then merged with the Dwight's file, thereby coding the Dwight's wells to tight/nontight status. Over half of the FERC-121 recurds were easiiy matched to the Dwight's data, while the remainder required manual editing of the field, reservoir, and lease names in order to match the FERC-121 filing to a Dwight's well record.

When all of the FERC-121 filings were matched to the Dwight's well records, a subset of the Dwight's data that included all reservoirs that had any tight gas was created. The data presented in this report were prepared primarily from that subset. In some cases, individual local reservoir data were rationally grouped into larger, more regional entities. For example, data presented here for the Pettit reservoir of the East Texas Basin includes individual local reservoir records labeled Pettit Upper, Pettit Lower, Pettit 6800, and Pettit 7500. An insuperable data limitation exists for some basins in some States due to the fact that the FERC unfortunately did not require the use of standard geology-based reservoir names. In those states where the State regulatory body that certified compliance with the FERC's tight gas requirements allowed local reservoir names to be used (for example, the "10500 sand," which conveys information only about the depth of the producing interval), it was usually impossible as a practical matter to establish a correspondence between the local reservoir name and the correct geology-based reservoir name. Consequently, the by-reservoir-unit production data for some basins in some states is absent or sparse, or underrepresents the by-unit volume(s) in those instances where mixed name types were accepted on an either/or basis.

For the Appalachian region, a different method had to be used to determine pe-/well production since the Dwight's data are unavailable for that region. The FERC-121 filings include a filing date and the producer's estimate of production. These variables, plus the well completion date obtained from API well tickets, were used to create an initial level of production for each well. This initial production was then reasonably declined each year. The resulting annual sums for all Appalachian wells, not just those producing from tight reservoirs, were then compared to published production totals for the Appalachian States. Prorated edits that resulted from the comparison were then applied to each well, as necessary, to derive a final estimated annual production by well. 


\section{U.S. Basins with Tight Gas Production}

According to a 1992 National Petroleum Council (NPC) study, United States nonconventional gas resources including tight gas, Devonian/Antrim shales, and coalbed methane, amount to 1,065 trillion cubic feet, subject to the application of currently available exploration and production technologies. ${ }^{24}$ Tight gas accounts for 232 trillion cubic feet of that total, with the Rocky Mountain basins containing 53 percent. Twelve percent is in the Arkla/East Texas basins, 9 percent is in the Midcontinent area, 8 percent is in each of the Texas Gulf Coast and Permian basins, 6 percent is in the Appalachian Basin, and 4 percent occurs in all other basins. (A map showing locations of the major tight-gas-containing basins appears as Figure 1.) Assuming the application of advanced technology as defined in its study, the NPC estimates that tight gas resources would amount to 349 trillion cubic feet--some 117 trillion cubic feet more--and total nonconventional gas resources would amount to 1,295 trillion cubic feet. The NPC also predicts that tight gas production will account for about one-half of the domestic gas supply by the year 2030 .

There have been a number of other studies which have estimated tight gas resources. ${ }^{25}$ In 1973 the Federal Power Commission estimated 600 trillion cubic feet of gas-in-place in three western basins, the Green River, Piceance, and Uinta basins. ${ }^{26}$ Gas-in-place is the total amount of gas trapped in the reservoirs, not the technically recoverable portion thereof, or the technically and economically recoverable portion thereof, each of which is volumetrically smaller than the preceding category. In 1978, FERC added the Northern Great Plains (130 trillion cubic feet) and the San Juan Basin (63 trillion cubic feet) for a total of 793 trillion cubic feet of gas-in-place. ${ }^{27}$

Lewin and Associates, in 1978, estimated 423 trillion cubic feet of tight gas-in-place from the most prospective formations of 13 basins to a depth of 12,700 feet. $^{28}$ In 1980, the National Petroleum Council (NPC) expanded the Lewin study to 113 known and sxpected tight gas areas and basins and to a depth of 15,000 feet, resulting in estimates of 444 trillion cubic feet of gas-in-place from 10 basins and another 480 trillion cubic feet located in additional potentially productive basins. ${ }^{29}$ In the period 1987-1990, the U.S. Geological Survey (USGS) estimated 5,063 trillion cubic feet of gas-in-place in the Green River Basin and 423 trillion cubic feet in the Piceance Basin. ${ }^{30} 31$ In 1990-1991, ICF Resources estimated resources of tight gas-in-place for three basins--the East Texas Basin (31 trillion cubic feet), the San Juan Basin (17 trillion cubic feet), and the Piceance Basin

${ }^{24}$ National Petroleum Council, The Potential for Natural Gas in the United States, p. 93.

${ }^{25}$ National Petroleum Council, The Potential for Natural Gas in the United States, p. 94.

${ }^{26}$ Federal Power Commission, National Gas Survey, Volume 2 - Task Force Report of the Supply-Technical/Advisory Task ForceNatural Gas Technology (Washington, DC, 1973).

${ }^{27}$ Federal Energy Regulatory Commission, National Gas Survey: Nonconventional Natural Gas Resources, DOE/FERC-0010 (Washingtọn, DC, June 1978).

${ }^{28}$ V.A. Kuuskraa, et al., Enhanced Recovery of Unconventional Gas, Vol. II (Washington, DC: Lewin and Associates, Inc., October 1978).

${ }^{29}$ National Petroleum Council, Unconventional Gas Sources, Volume V: Tight Gas Reservoirs-Parts I and II (Washington, DC, December 1980).

${ }^{30}$ B.E. Law, et al., "Estimates of Gas Resources in Over-Pressured Low-Permeability Cretaceous and Tertiary Sandstone Reservoirs, Greater Green River Basin, Wyoming, Colorado, and Utah," in Gas Resources of Wyoming, 40th Annual Field Conference 1989 (Casper, WY: Wyoming Geological Association), pp. 39-61.

${ }^{31}$ R.C. Johnson, et al., An Assessment of Gas Resources in Low Permeability Sandstones of the Upper Cretaceous Mesaverde Group, Piceance Basin, Colorado (Washington, DC, U.S. Geological Survey Open File Report 87-357, 1987). 


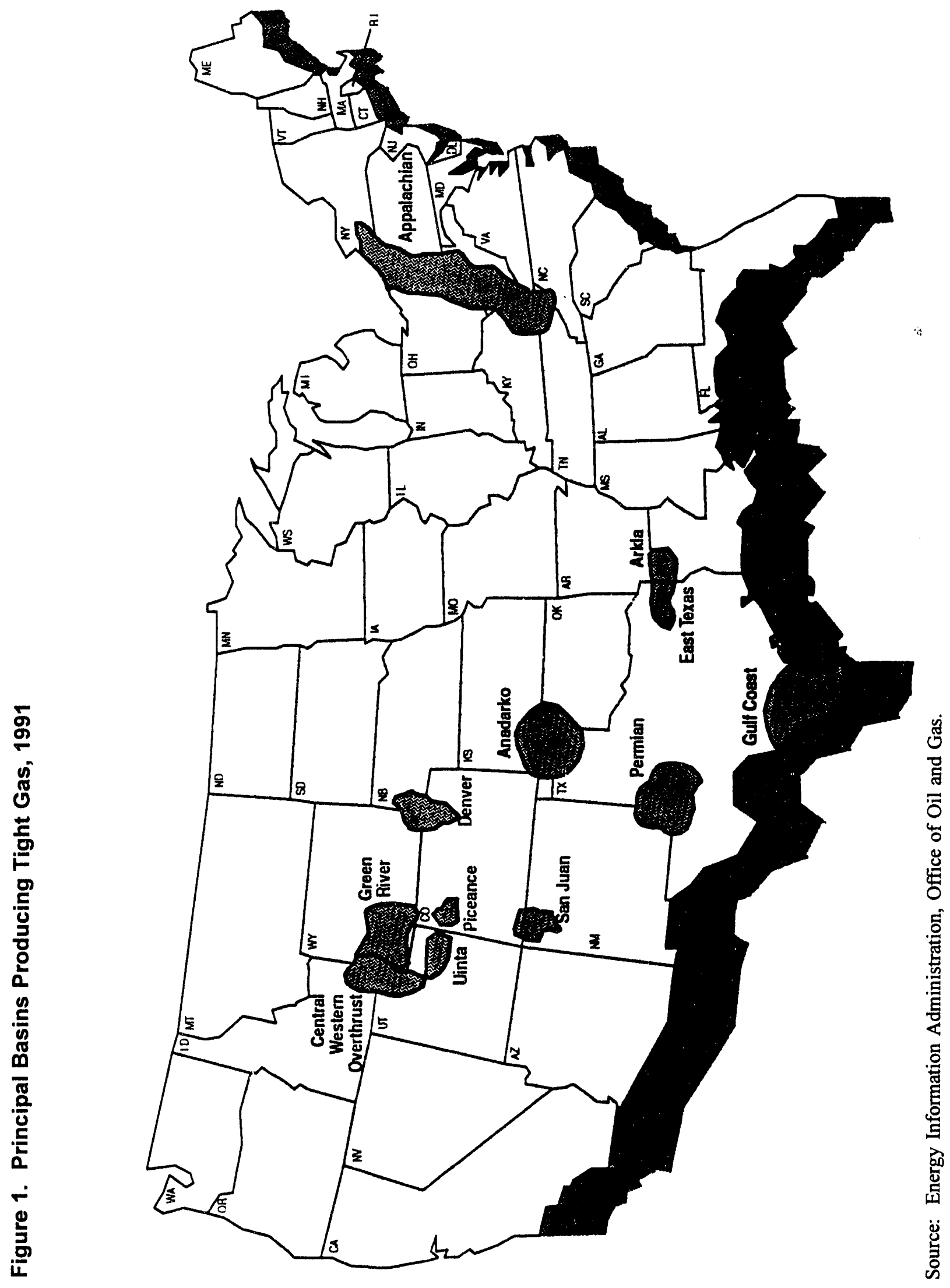


(287 trillion cubic feet). ${ }^{32} 3334$ Finally, in 1991, Enron Corporation estimated that 201 trillion cubic feet of recoverable tight gas are present in the United States. ${ }^{35}$

Unfortunately, there are no estimates of proved gas reserves, from any source, that distinguish between tight gas and other types of proved gas reserves. Based on the data gathered for this report, at year end 1991 the largest tight gas production volumes came from the Gulf Coast Basin, followed in decreasing order by the East Texas, Appalachian, Permian, and Denver basins. These and other basins with lesser production volumes are discussed more specifically below.

\section{The Gulf Coast Basin (Onshore)}

The Gulf Coast Basin is located in southern and southeastern Texas and southern Louisiana. It includes parts of both the Mississippi and the Rio Grande embayments. It is structurally bounded on the north and west by the Balcones Fault Zone and the Ouachita Tectonic Belt. ${ }^{36}$ In 1991, its tight gas production was 363.6 billion cubic feet, almost all of it from the Texas portion of the basin. Tight gas reservoirs are located in the deeply buried downdip portions of Tertiary formations, where sandstones are interbedded with shales. ${ }^{37}$ In 1991 , the most prolific reservoir, the Eocene Wilcox Lobo, located in Webb and Zapata Counties of south Texas, produced 243 billion cubic feet cf natural gas.

The Wilcox Lobo is a geologically complex formation that was deposited in both shallow and deep marine environments. The main gas-producing areas are in downdip areas deposited in large deltas and barrier/strandplain systems. ${ }^{38}$ The Wilcox Lobo was subject to several cycles of erosion and deformation which caused the reservoir to become more complex both stratigraphicaliy and structurally. The sandstones contain shale and quartz cement, which results in their low porosity and permeability. There has been extensive faulting of the reservoir, with resulting lateral discontinuities. ${ }^{39}$ The Wilcox Lobo, which is from 10 to 60 feet thick, has porosities ranging from 12 percent downdip to as high as 25 percent in updip areas. The permeability to gas ranges from 0.0003 to 0.5 millidarcy. Temperatures and pressures are high, causing problems for drilling, logging, and completion operations. $^{40}$

${ }^{32}$ M.R. Haas, Impact of Improved Technology on Potential Reserves of Tight Gas in East Texas and North Louisiana, report GRI90/0174 prepared firr Gas Research Institute (Fairfax, VA: ICF Resources, Inc., September 1990).

${ }^{33}$ M.R. Haas, Technical and Economic Evaluation of Low Permeability Sandstones Within the Mesaverde Group, Piceance Basin, Colorado, report prepared for the Office of Fossil Energy, U.S. Department of Energy (Fairfax, VA: ICF Resources, Inc., March 1991).

${ }^{34}$ M.R. Haas and T.E. Crist, A Geologic Assessment of Natural Gas from Tight Gas Sandstones in the San Juan Basin, prepared for the Morgantown Energy Technology Center, U.S. Department of Energy (Fairfax, VA: ICF Resources, Inc., May 1991).

${ }^{35}$ Enron Corporation, Enron Corporation's Outlook for Natural Gas: Fueling the Future into the 21st Century (Houston, TX: Enron Corporation, 1990).

${ }^{36}$ Potential Gas Committee, Potential Supply of Natural Gas in the United States, 1988 (Golden, CO: Potential Gas Agency, 1989), p. 52.

${ }^{37}$ S.P. Dutton, et al., Atlas of Major Low-Permeability Sandstone Gas Reservoirs in the Continental United States, p. 133.

${ }^{38}$ E.C. Kosters, et al., Atlas of Major Texas Gas Reservoirs (Austin, TX: The University of Texas Bureau of Economic Geology, 1989).

${ }^{39}$ S.P. Dutton and S.E. Laubach, "Comprehensive Geologic Basin Analysis: Application of a Generic Research Approach to Several Tight Gas Sandstone Formations," p. 28.

${ }^{40}$ S.P. Dutton, et al., Atlas of Major Low-Permeability Sandstone Gas Reservoirs in the Continental United States, p. 150. 


\section{The East Texas Basin}

The East Texas Basin is located primarily in the northeastern portion of Texas. Gas was first found during the 1940 's in the adjacent Louisiana portion's Jurassic Cotton Valley Sandstone, a porous "blanket" sand probably deposited as part of wave-dominated deltas in strandplain, barrier island, and tidal bar environments. The present area of tight gas development in the Cotton Valley is downdip of this area, along the flanks of the Sabine Uplift in Texas and in the deeper parts of the East Texas Basin. The Cotton Valley tight gas reservoirs are discontinuous, have low permeabilities, and were probably deposited as prodelta, delta-front, and braided stream facies, perhaps reworked during subsequent sea transgressions and regressions. ${ }^{41}$ Tight gas production from the Cotton Valley Sandstone in 1991 was 239.8 billion cubic feet, making it the largest tight gas producer in the basin. Overall, Texas was by far the largest tight gas producer in 1991, at 793 billion cubic feet.

\section{The Appalachian Basin}

The Appalachian Basin encompasses portions of the States of Alabama, Georgia, Kentucky, Maryland, New Jersey, New York, Ohio, Pennsylvania, Tennessee, and Virginia, and virtually all of West Virginia. It is structurally bounded on the east by the Appalachian Mountains and on the west by the Cincinnati Arch and Nashville Dome. ${ }^{42}$ The most prolific Appalachian tight-gas-producing States in 1991 were, in order from highest to lowest, Ohio, Pennsylvania, West Virginia, New York, Virginia, and Kentucky. Total tight gas production for the basin in 1991 was 257 billion cubic feet, making it the third largest tight-gas-producing basin in the United States. Ohio was second only to Texas in 1991 tight gas production, at 101 billion cubic feet, the bulk of which came from the Silurian Clinton and Lower Mississippian Berea formations. ${ }^{43}$

The Clinton sandstone is of early Silurian age and is productive in New York, Pennsylvania, and Ohio. It occurs in the relatively undeformed Western Basin Province of the Appalachian Basin. It was deposited as lenticular to almost blanket sandstones in a deltaic to marginal marine strandplain environment. ${ }^{44}$ The Berea Sandstone of the Lower Mississippian Pocono Group is composed of fine- to medium-grained sandstone and siltstone, with some interbedded shale. It is present in the subsurface of Ohio, Pennsylvania, West Virginia, and Kentucky. It was deposited as part of a wave-dominated progradational clastic wedge. There are both blanket reservoirs, such as barrier bars, and lenticular reservoirs deposited as fluvial channels. ${ }^{45}$

The Dwight's data do not cover the Appalachian Basin states, so estimates of individual reservoir unit production could not be calculated. Also, the EIA's methodology for estimating the Appalachian Basin states' tight gas production differs from that used for the rest of the country due to the lack of detailed data, as explained earlier.

${ }^{41}$ R.J. Finley, Geology and Engineering Characteristics of Selected Low-Permeability Sandstones: A National Survey (Austin, TX: University of Texas Bureau of Economic Geology Report of Investigations No. 138, 1984), p. 69.

${ }^{42}$ Potential Gas Committee, Potential Supply of Natural Gas in the United States, 1988, p. 25.

${ }^{43}$ S.P. Dutton and S.E. Lauuach, "Comprehensive Geologic Basin Analysis: Application of a Generic Research Approach to Several Tight Gas Sandstone Formations," p. 27.

${ }^{44}$ R.J. Finley, Geology and Engineering Characteristics of Selected Low-Permeability Sandstones: A National Survey, p. 42.

${ }^{45}$ R.J. Finley, Geology and Engineering Characteristics of Selected Low-Permeability Sandstones: A National Survey, p. 42. 


\section{The Permian Basin}

The Permian Basin is located in Texas and New Mexico. It is structurally bounded on the east by the Bend Arch, on the north by the Amarillo-Ouachita Uplift, on the west by the Sacramento Mountains, on the southwest by the Diablo Platform, and on the south by the Marathon Thrust Belt. ${ }^{46}$ The basin as a whole produced 140 billion cubic feet of tight gas in 1991. Most of the production was from the Texas portion (119 billion cubic feet). The largest tight-gas-producing reservoir by far was the Pennsylvanian Canyon Group, at 93 to 105 billion cubic feet depending on how the data are aggregated by formation, age, group, and similar factors.

The Canyon Group was deposited in the Late Pennsylvanian and Early Permian in submarine fan systems. The largest and most prolific fields, such as the Ozona, Sawyer, and Sonora fields, are productive from thick sandstones comprised of turbidites deposited in a submarine slope environment. ${ }^{47}$ The sandstones have low permeability as a result of the presence of clay and cement filling the pore spaces. Porosities average less than 5 percent and permeabilities less than 0.1 millidarcy.

\section{The Denver Basin}

The Denver Basin is located in eastern Colorado, southwestern Nebraska, and southeastern Wyoming. It is bounded on the southeast by the Las Animas Arch, on the northeast and east by the Chadron-Cambridge arches, on the north and northwest by the Hartville Uplift, on the west by the Laramie Mountains and the Front Range, and on the south by the Apishapa Uplift. ${ }^{48}$ It is a foreland asymmetric basin with a steep western flank and a gently sloping eastern flank, formed as a result of the uplift of the Front Range during the Laramide Orogeny.

In 1991, the Denver Basin produced 57.5 billion cubic feet of tight gas, mostly from two Cretaceous formations, the J Sandstone and the Niobrara Formation. The most prolific producing formation and field in the Denver Basin are, respectively, the J Sandstone and the Wattenberg Field. The J Sandstone produced almost 23 billion cubic feet in 1991, and the Niobrara Formation produced 20.5 billion cubic feet. The J Sandstone is a member of the Lower Cretaceous Dakota Group, which was deposited as part of the infilling of the Western Interior Basin Sea in coastal plain, fluvial, deltaic, and nearshore marine environments. ${ }^{49}$ An estimate of the ultimate gas recovery from the J Sandstone in Wattenberg Field is 1.3 trillion cubic feet. ${ }^{50}$ Gas migrated into the area of the present Wattenberg Field when it was a structural high. Subsequent deformation in the Denver Basin has caused the field to become a structural low, but the gas has remained trapped through a combination of stratigraphic and diagenetic effects. $^{31}$ Porosities range from 8 to 12 percent and permeabilities average 0.0059 millidarcy.

${ }^{46}$ Potential Gas Committee, Potential Supply of Natural Gas in the United States, 1988, p. 63.

${ }^{47}$ S.P. Dutton and S.E. Laubach, "Comprehensive Geologic Basin Analysis: Application of a Generic Research Approach to Several Tight Gas Sandstone Formations," p. 21.

${ }^{48}$ Potential Gas Committee, Potential Supply of Natural Gas in the United States, 1988, p. 77.

${ }^{49}$ R.J. Weimer and S.A. Sonnenberg, "Sequence Stratigraphic Analysis of Muddy (J) Sandstone Reservoir, Wattenberg Field, Denver Basin, Colorado," in E.B. Coalson, ed., Petrogenesis and Petrophysics of Selected Sandstone Reservoirs of the Rocky Mountain Region (Rocky Mountain Association of Geologists, 1989), pp. 197-220.

${ }^{50}$ J.A. Momper, "Denver Basin, Lower Certaceous, J Sandstone Tight Reservoir Potential," in Geochemistryfor Geologists (American Association of Petroleum Geologists, short course notes, 1981), pp. 1-15.

${ }^{5 t}$ R.J. Weimer, et al., "Wattenberg Field, Denver Basin, Colorado," in C.W. Spencer and R.F. Mast, eds., Geology of Tight Reservoirs (American Association of Petroleum Geologists, Studies in Geology No. 24, 1986), pp. 143-164. 


\section{The Green River Basin}

The Green River Basin is located in southwestern Wyoming, northeastern Utah, and northwestern Colorado. It is a Laramide Foreland basin, located to the east of the Overthrust Belt. Most tight gas production is from the Cretaceous Frontier and Mesaverde formations. ${ }^{52}$ The Frontier and the Mesaverde both consist of regressive cycles deposited in fluvial, shoreline, and marine-shelf environments. ${ }^{53}$ The Frontier Formation is designated tight in fields along the Moxa Arch, the Rock Springs Uplift, and in parts of the Washakie Basin. The Mesaverde Formation is designated tight throughout much of the basin east of the Rock Springs Uplift. The production information for the Green River Basin is mostly without detail, so no separate estimates are provided for these formations. In 1991, tight gas production from the Green River Basin was 40.2 billion cubic feet, all from the Wyoming portion.

\section{The Anadarko Basin}

The Anadarko Basin is located in western Oklahoma and northeastern Texas. It is a very deep, asymmetric structural and depositional basin containing over 40,000 feet of sedimentary rocks. It is a result of a Pennsylvanian Age orogeny that affected much of the South-Central United States. ${ }^{54}$ In 1991, it produced 26.6 billion cubic feet of tight gas, consisting of 16 billion cubic feet from Texas and 10.5 billion cubic feet from Oklahoma. The most significant producing formations were the Pennsylvanian Granite Wash and Cleveland formations, with 6.3 and 9.1 billion cubic feet of tight gas production, respectively. The Granite Wash Formation was deposited as fluvial sediments in alluvial fans shed from the Amarillo Uplift. ${ }^{55}$ The Cleveland Formation was deposited in a deltaic environment. ${ }^{56}$

\section{The Central Western Overthrust}

The Central Western Overthrust is located in western Wyoming, northeastern Utah, and southeastern Idaho. It was complexly folded and thrust-faulted during the Laramide Orogeny of Cretaceous and early Tertiary time, which has made its exploration difficult and expensive. ${ }^{57}$ Tight gas production is confined to the Wyoming portion of the area. In 1991, the Overthrust Belt produced 18.7 billion cubic feet of tight gas, 15 billion cubic feet of that being from the Cretaceous Frontier Formation.

${ }_{52}$ R.H. Hugman, P.S. Springer, and E.H. Vidas, Tight Gas Field, Reservoir, and Completion Analysis of the United States, pp. 2-3.

${ }^{53}$ B.E. Law, et al., "Estimates of (ias Resources in Overpressured Low-Permeability Cretaceous and Tertiary Sandstone Reservoirs, Greater Green River Basin, Wyoming, Colorado, and Utah," pp. 39-61.

${ }^{54}$ W.E. Ham and J.L. Wilson, "Palcozoic Epeirogeny and Orogeny in the Central United States," American Journal of Science 265, 5 (May 1967), pp. 332-407.

54 S.P. Dutton, "Pennsylvanian Fan-Delta and Carbonate Deposition, Mobeetie Field, Texas Panhandle," in American Association of Petroleum Geologist Bulletin 66, 4 (April 1982), pp. 389-407.

so T.F. Hentz, "Low-Permeability, Gas-Bearing Cleveland Formation (Upper Pennsylvanian), Western Anadarko Basin: Structure, Paleoenvironments, and Paleotectonic Control on Depositional Patterns," in Transactions, Southwest Section of the American Association of Petroleum Geologists, Pub. SWS 92-90, 1992, pp. 231-252.

${ }^{37}$ Potential Gas Committee, Potential Supply of Natural Gas in the United States, 1988, p. 96. 


\section{The San Juan Basin}

The Saiı Juan Basin, another Laramide structural feature, is one of the major gas-producing areas in the United States. It is located in northeastern New Mexico and extreme southwestern Colorado, and is structurally bounded on the south by the Zuni Uplift, on the west by the Defiance Uplift, on the north by the San Juan Uplift, and on the east by the Naciemento Uplift. The basin contains about 15,000 feet of sedimentary rocks. ${ }^{58}$ In 1991 , it produced 17.8 billion cubic feet of tight gas, 6.9 billion cubic feet from Colorado and 10.9 billion cubic feet from New Mexico. The major producing units are the Dakota and Mesaverde formations, both of which were deposited during transgressions and regressions of Cretaceous seas. ${ }^{59}$ The Dakota Formation produced 7.9 billion cubic feet of tight gas and the Mesaverde 3.6 billion cubic feet.

\section{The Uinta Basin}

The Uinta Basin of northeastern Utah is bounded on the north by the Uinta Mountains, on the west by the Wasatch Range, on the south by the San Rafael Swell and Uncompaghre Uplift, and on the east by the Douglas Creek Arch. The basin, formed during the Laramide Orogeny, is asymmetric and east-west trending, with more than 30,000 feet of sedimentary rocks. ${ }^{60}$ In 1991 , the basin produced 15.9 billion cubic feet of tight gas, 15.2 billion cubic feet of which came from the Paleocene (Tertiary) Wasatch Formation.

\section{The Arkla Basin}

The Arkla Basin of north-central Louisiana formed during Late Triassic rifting. ${ }^{61}$ The major tight-gas-producing formation is the Upper Jurassic to Lower Cretaceous Cotton Valley Sandstone. This formation was deposited as one of the first clastic units in northern Louisiana to be laid down after the opening of the Gulf of Mexico in Jurassic time. Because of the nature of the production data available for this area, only partial detail can be provided. The basin produced 15.8 billion cubic feet of tight gas in 1991, at least 5.2 billion cubic feet of which was from the Cotton Valley Sandstone.

\section{The Piceance Basin}

The Piceance Basin of northwestern Colorado is yet another Laramide Foreland basin. It is bounded on the northwest by the Uinta Mountains, on the north by the Axial Arch, on the east by the White River Uplift, on the southeast by the Elk Mountains and the San Juan Volcanic Field, and on the southwest by the Uncompahgre Uplift. $^{62}$ The basin produced 10.9 billion cubic feet of tight gas in 1991, 4.3 billion cubic feet from the Upper Cretaceous Mancos Shale and 2.9 billion cubic feet from the Lower Cretaceous Dakota Formation.

${ }^{58}$ Potential Gas Committee, Potential Supply of Natural Gas in the United States, 1988, p. 87.

${ }^{59}$ S.P. Dutton, et al., Allas of Major Low-Permeability Sandstone Gas Reservoirs in the Continental United States, p. 265.

60) Potential Gas Committee, Potential Supply of Natural Gas in the United States, 1988, p. 82.

${ }^{61}$ R.T. Buffler, et al., "Structure and Early Geologic History of the Deep Central Gulf of Mexico," in Proceedings, Symposium on the Origin of the Gulf of Mexico and the Early Opening of the Central North Atlantic Ocean (Baton Rouge, LA: Louisiana State University School of Geoscience, 1980), pp. 3-16.

${ }_{62}$ S.P. Dutton, et al., Atlas of Major Low-Permeability Sandstone Gas Reservoirs in the Continental United States, p. 323. 


\section{Other Basins with Tight Gas Production}

Table 1 lists tight gas production data for all of the basins in the EIA's data base that have such production. Several basins, mostly minor in 1991 relative to production, are listed that were not discussed above. Table 2 summarizes the tight gas production data by State. Note that the State totals that can be calculated from Table 1 will not necessarily match those in Table 2 due to accumulated rounding error differences. 


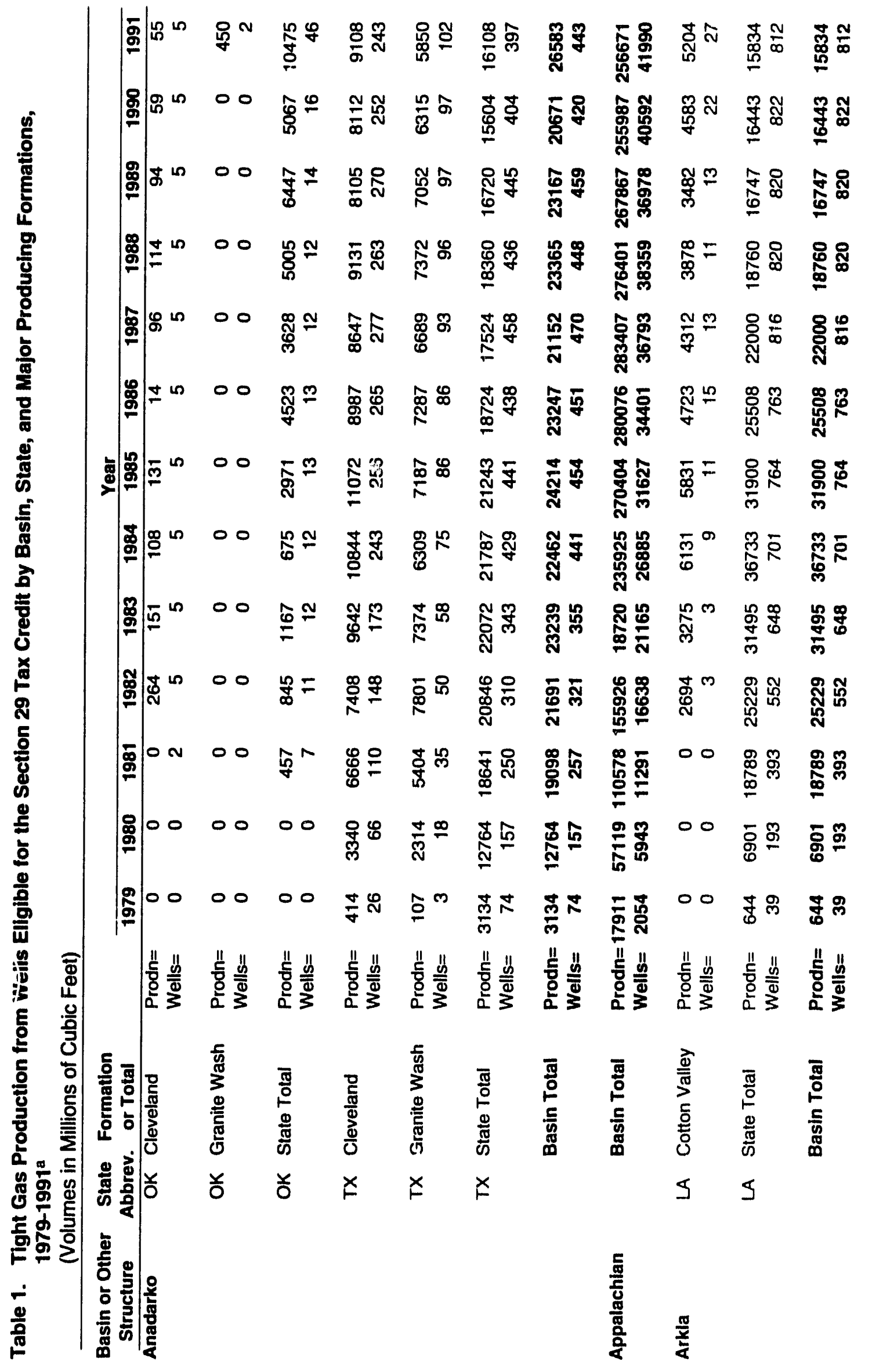

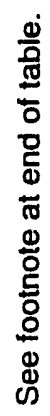




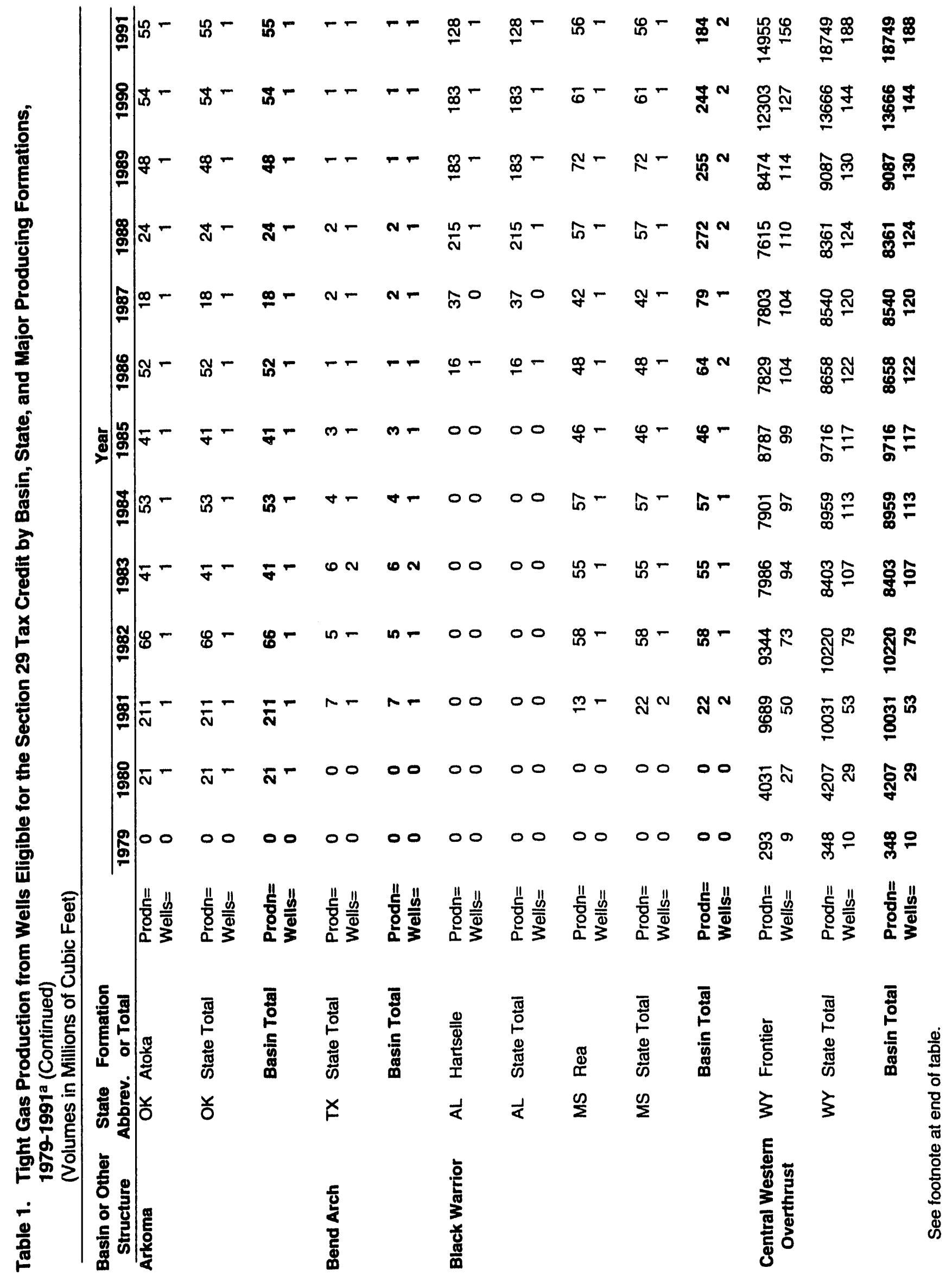




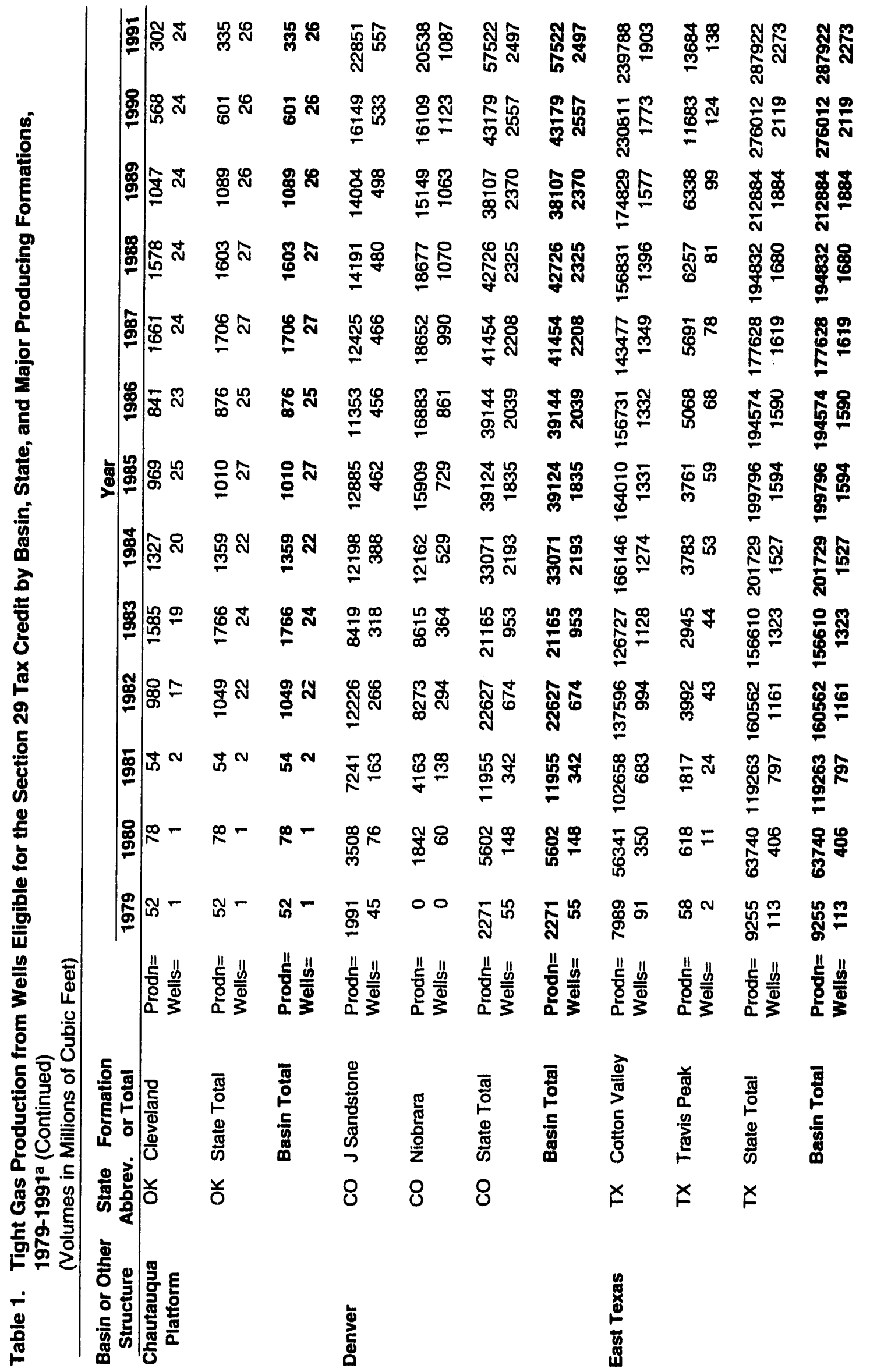




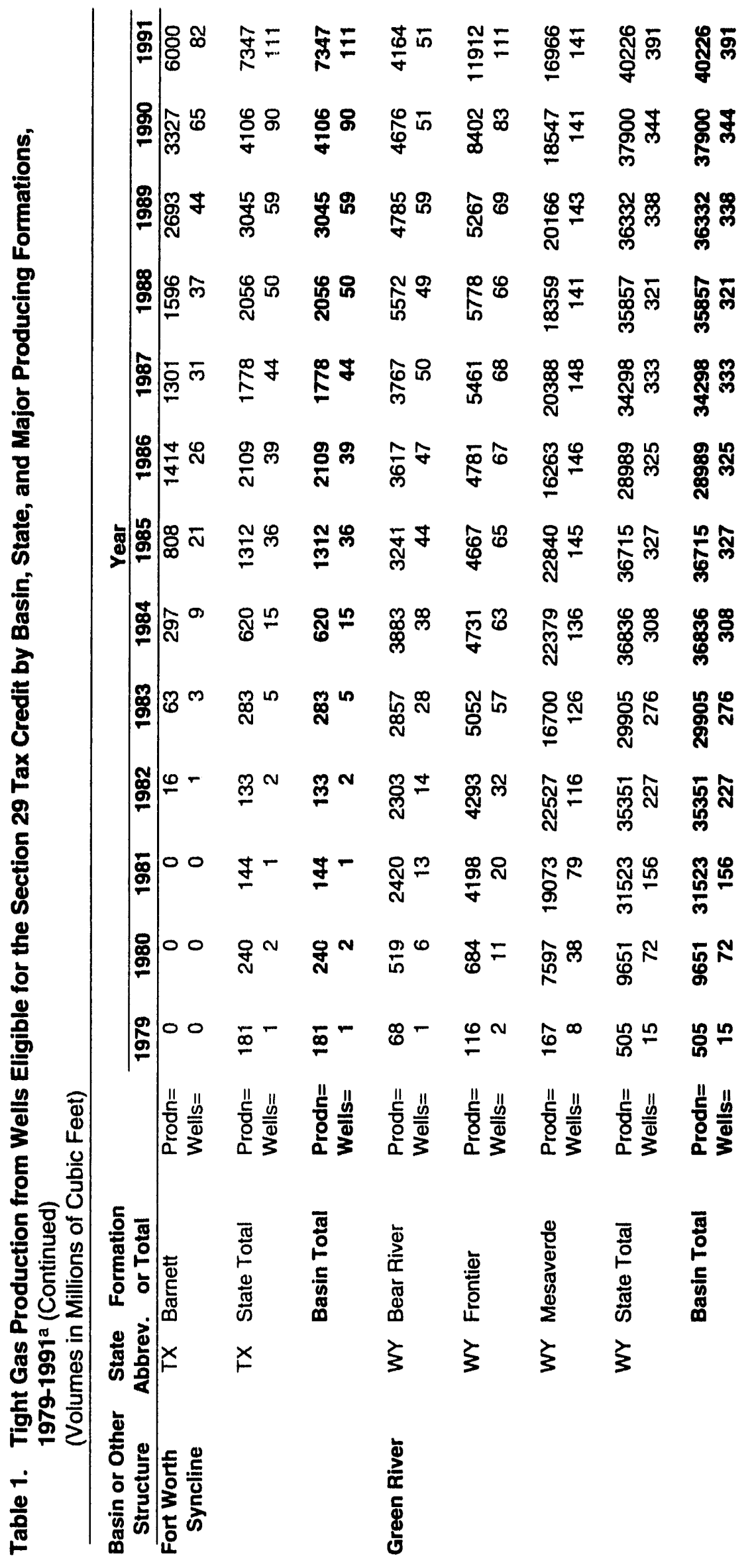




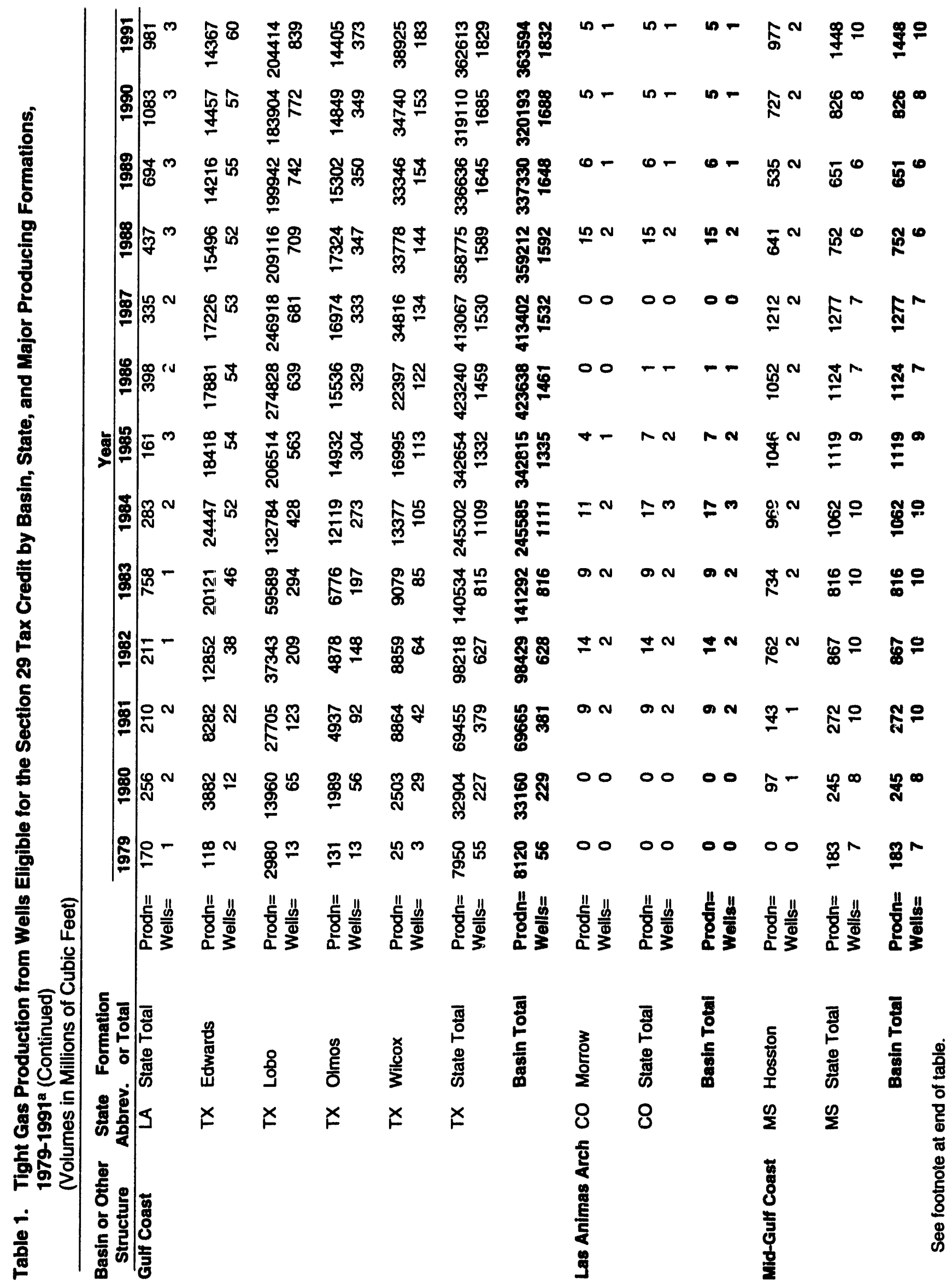




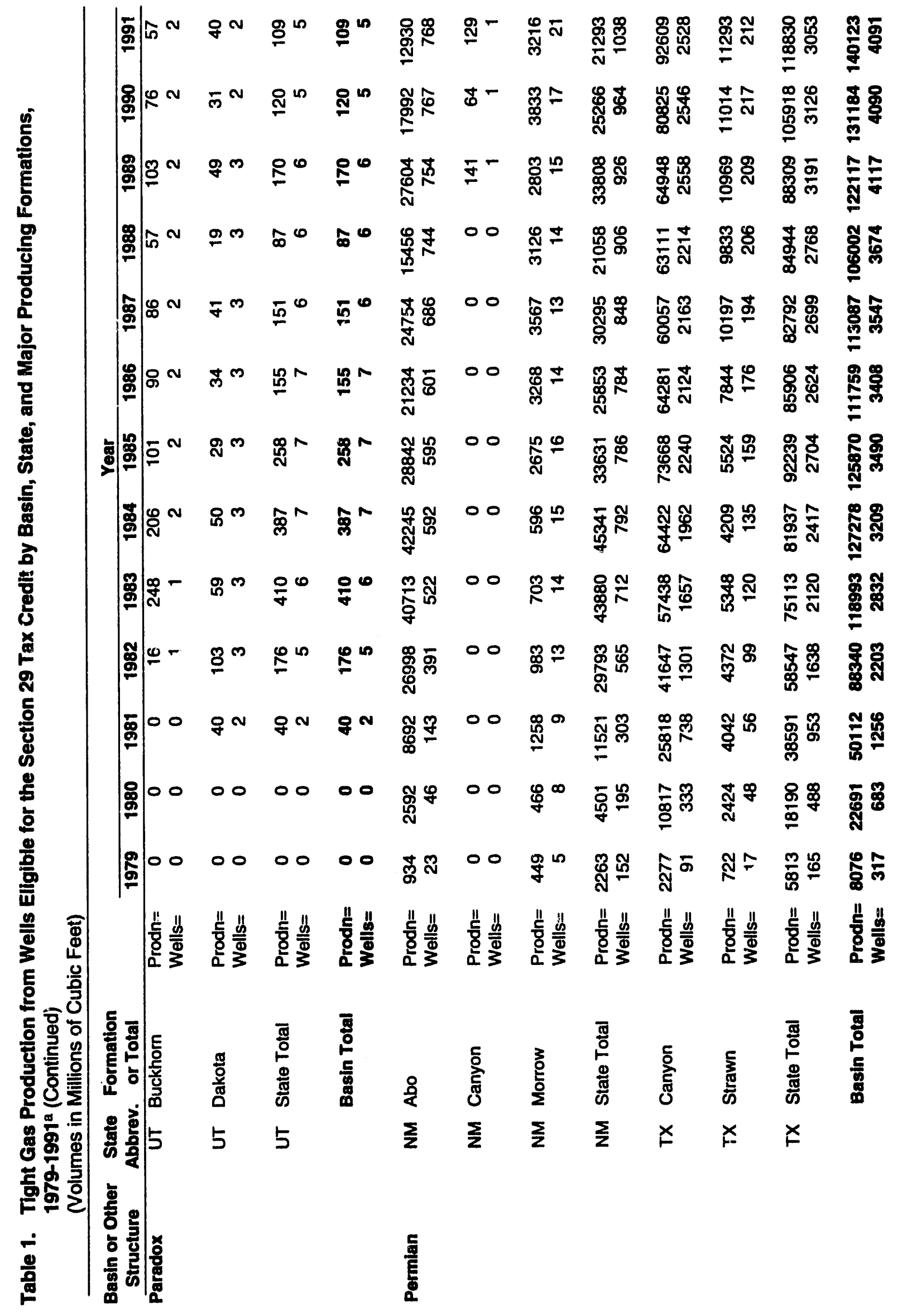




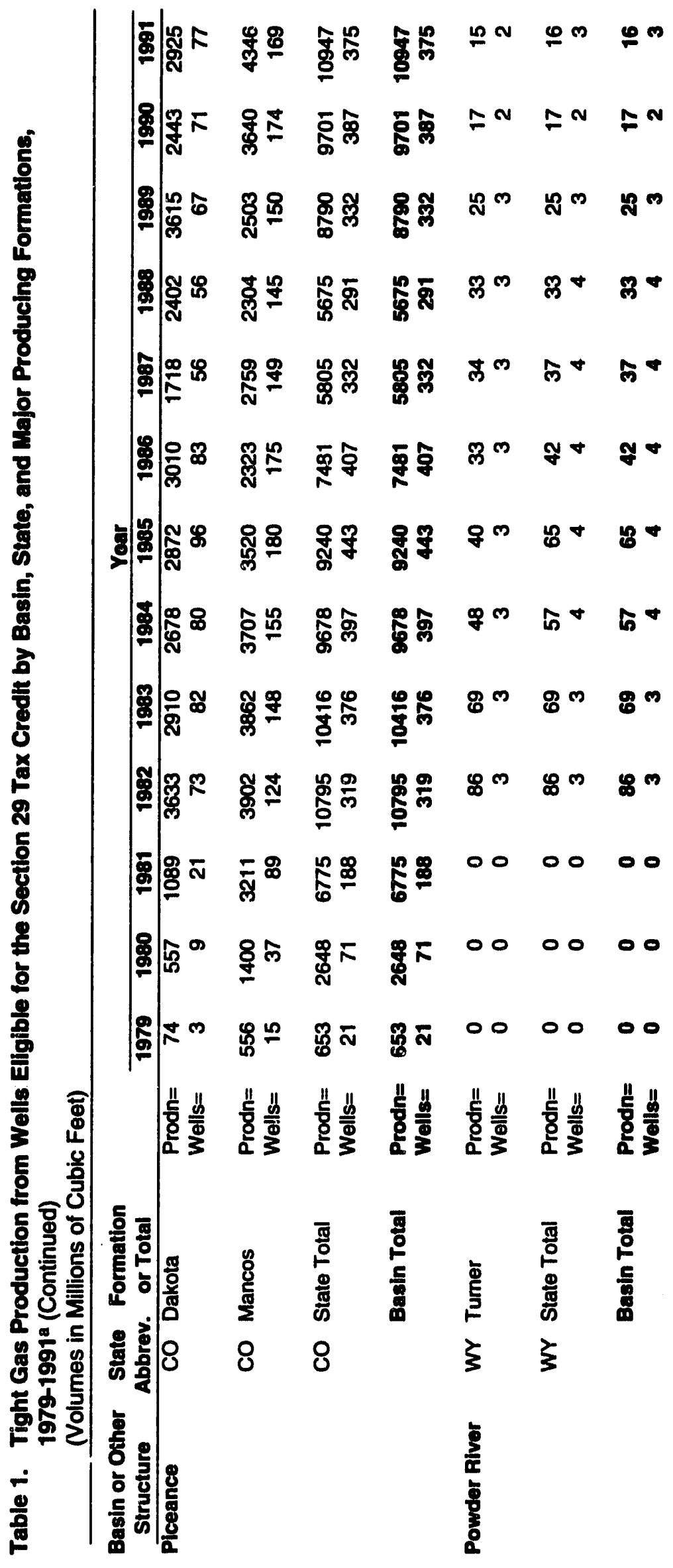




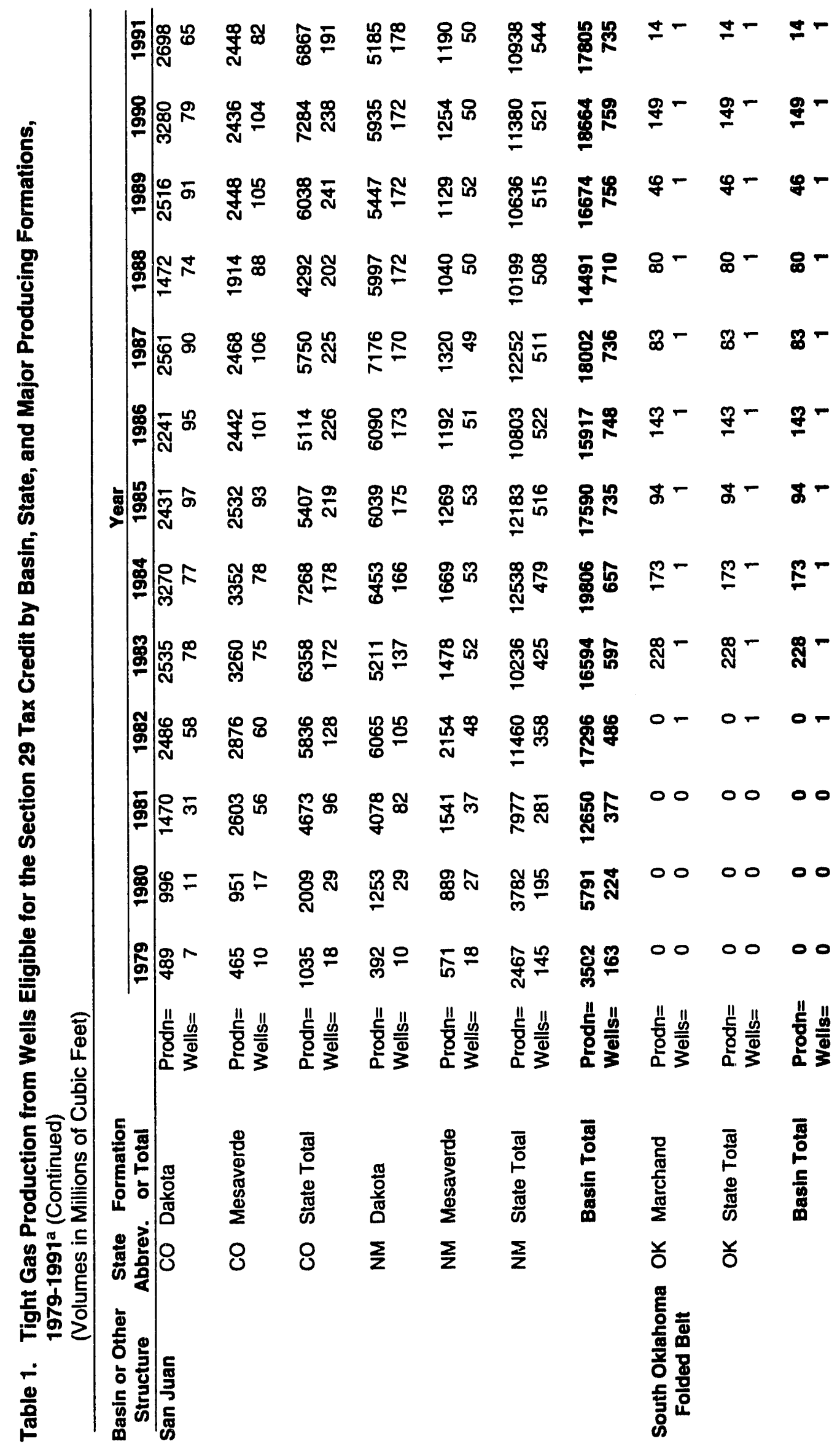




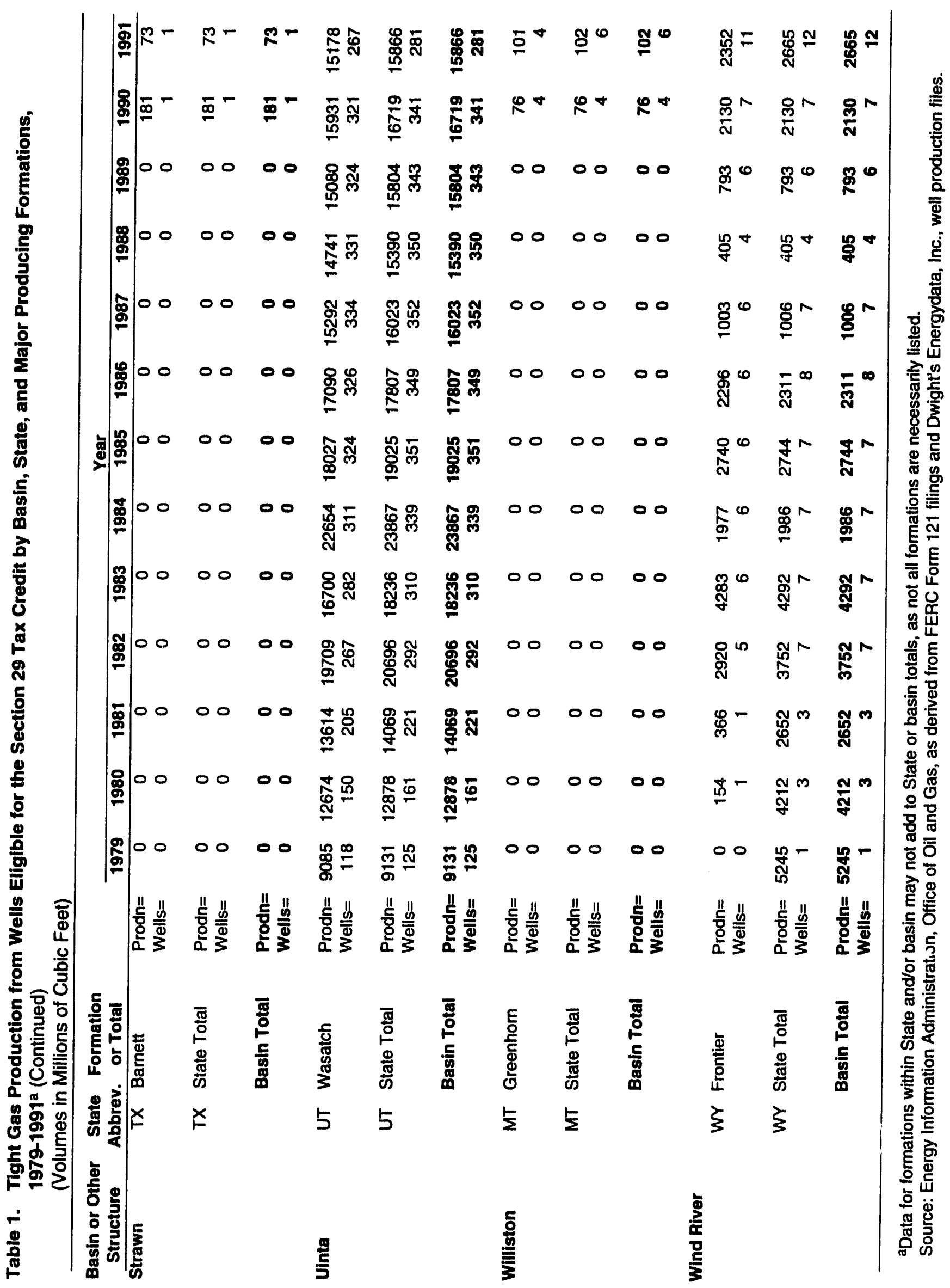




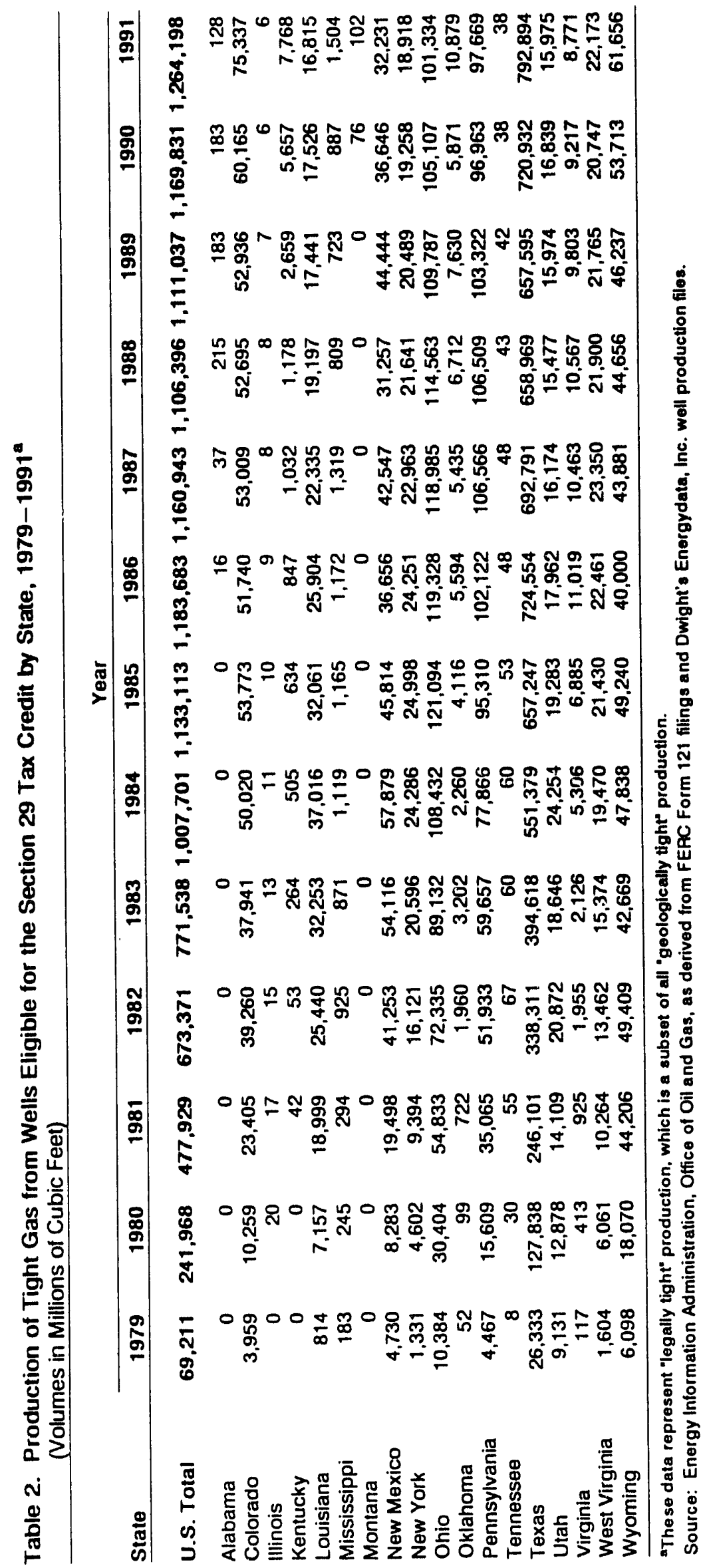




\section{Summary}

Responding to incentive gas prices provided under the Natural Gas Policy Act of 1978 and a special tax credit for new gas production provided under the Windfall Profits Tax Act of 1980, the United States gas industry increased its exploration and development activities relative to domestic nonconventional gas sources such as gas from low-permeability (tight) reservoirs. The EIA has assembled tight gas production data from 1979 to 1991. Prior EIA studies of tight gas production provided data through 1988. The present study updates the production data through 1991 and, for the first time, presents it by state, geologic basin, and (in many cases) by reservoir unit within basin. Twenty-nine basins were identified as having tight gas production in 1991, accounting for 1,264 billion cubic feet of production, which amounted to about 7 percent of total United States gas production.

Because the EIA's production data are based only on wells located in areas designated tight by the Federal Energy Regulatory Commission (FERC), production from a given formation does not appear in the EIA's tight gas data base until approval by the FERC or a FERC-designated State agency. The EIA's production data are therefore only for "legally tight" gas, and the recorded production steadily increases over time from 1979 to 1991. Tight gas production from all reservoirs that are "geologically tight" would likely show a different trend. According to a previously cited study conducted by Energy and Environmental Analysis, Inc. for the Gas Research Institute, which covered overall tight gas production through 1988, 1985 was the year of peak total tight gas production. This is not an unexpected result, as the highest national annual average wellhead gas prices occurred in the 1982 to 198.5 period; the highest, $\$ 2.58$ per million Btu, occurred in 1984 . Thereafter prices dropped rapidly to a low of $\$ 1.59$ per million Btu in 1991, a factor of 38 percent. As a consequence, many marginal tight gas wells that were not eligible for the tax credit, for whatever reason, were undoubtedly plugged and abandoned post-1985.

Now that both the incentive prices and the tax credit are expired for new wells, it is a matter of conjecture what trend tight gas drilling will follow. However, without tax or price incentives, it is unlikely that companies will explore heavily for tight gas, barring the advent of significantly higher overall gas price levels. Therefore, the most likely present outlook is that new drilling for tight gas will decrease post-1993. 

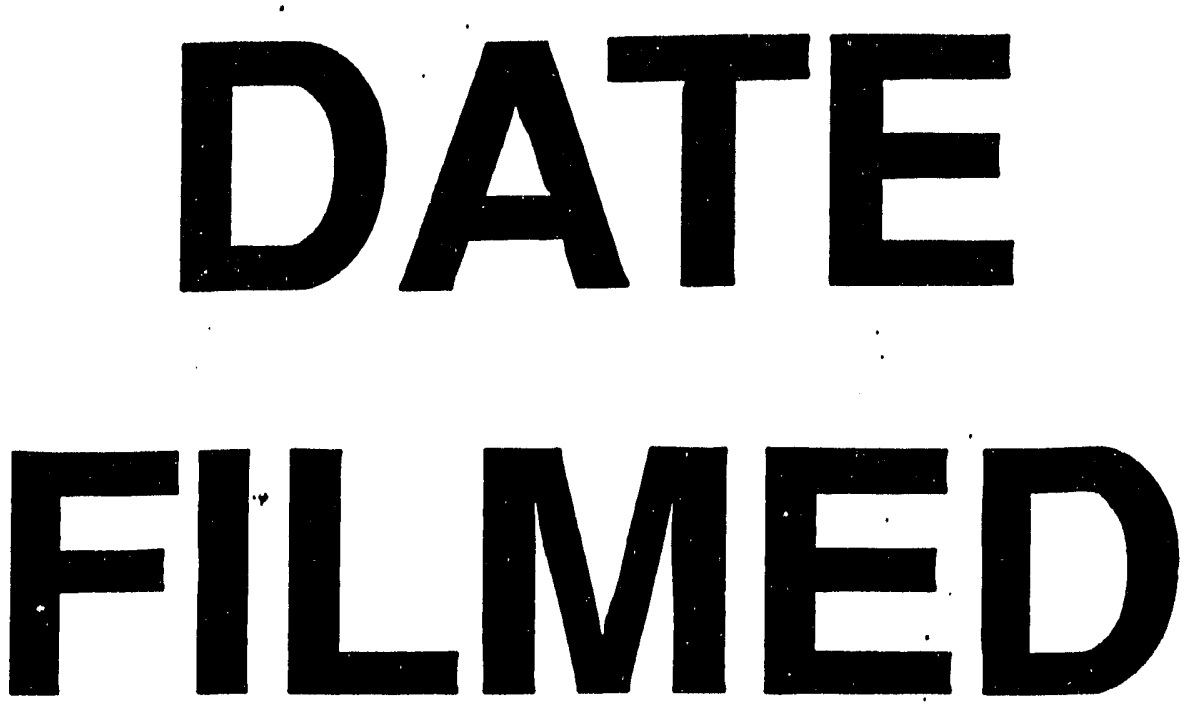

$12 / 13 / 93$
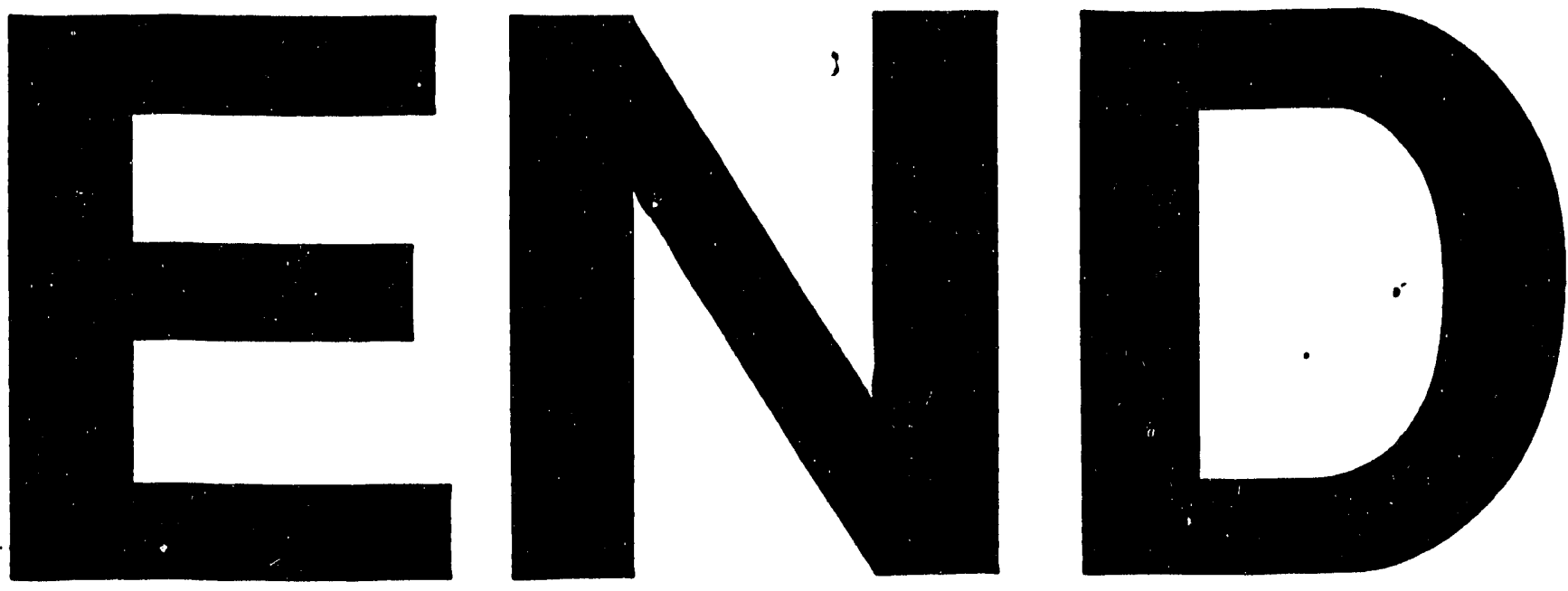
